\title{
UNIVERSITY OF PENNSYLVANIA RADIOCARBON DATES XIX
}

\section{BERNARD FISHMAN, HAMISH FORBES, and BARBARA LAWN \\ Department of Physics and University Museum, \\ University of Pennsylvania, Philadelphia, Pennsylvania 19174}

\section{INTRODUCTION}

This date list includes most of the archaeologic and geologic samples dated in this laboratory since publication of our last date list $(\mathrm{R}, 1975$, $\mathrm{v} 17, \mathrm{p}$ 196-215) as well as many samples dated previously which lacked adequate sample information.

The BP ages are based on AD 1950, and have been calculated with the half-life value of $5568 \mathrm{yr}$. An asterisk $\left({ }^{*}\right)$ before an $\mathrm{AD} / \mathrm{BC}$ date indicates a date that has been calculated with the half-life value of $5730 \mathrm{yr}$ and then corrected by means of MASCA correction factors. For further explanation see Univ of Pennsylvania Dates XVI (R, 1974, v 16, p 198-218) and Ralph et al, 1973.

All samples were counted at least twice for periods of not less than $1000 \mathrm{~min}$ each. Errors quoted for each sample include the sum of the statistical counting uncertainties in the measurement of the sample, the background, and several counts of our mid-19th century oak sample, but do not include the possible half-life errors. Corrected AD/BC errors quoted are the same as above, but do not include any additional errors associated with the correction factors.

In addition to our $28 \mathrm{~L}$ counters, a small $1 \mathrm{~L}$ counter has been constructed for counting undersized samples. Larger errors associated with these dates are a direct result of small sample size and consequent reduced number of counts. In all counters we continue to use pure $\mathrm{CO}_{2}$.

All samples were pretreated with $3 \mathrm{~N} \mathrm{HCl}$ and some, where noted, were given additional pretreatment with $2 \% \mathrm{NaOH}$ for the removal of possible humic acid contaminants.

Our mid-19th century calibration samples have an average age of 141 yr. When corrected for this age, they have ${ }^{14} \mathrm{C}$ contents equal to $95 \%$ of the NBS oxalic acid standard. The average ${ }^{13} \mathrm{C}$ relationship between the oak standard and the NBS limestone standard \#20 is $-25.7 \pm 1.3 \%$ as measured on the Univ of Pennsylvania mass spectrograph. Where ${ }^{13} \mathrm{C}_{\mathrm{w}}$ is reported, the ${ }^{13} \mathrm{C}$ relationship has been measured with respect to the oak standard and the results accordingly corrected for isotopic fractionation.

For the design and construction of new components, we wish to thank Raymond Costa and Jeffrey Klein. They, as well as the authors and previous graduate students, have processed the samples. In this date list, Bernard Fishman prepared the Egyptian and related dates for publication; Hamish Forbes, the Aegean and other dates; Barbara Lawn, the introduction, general supervising, and editing.

\section{ACKNOWLEDGMENTS}

We acknowledge with gratitude the financial support of the National Science Foundation, through continuing grant DES-74-22233 for the 
known-age dating program at Univ Pennsylvania, which has resulted in the MASCA correction factors used in this date list. We are grateful too, to the William Penn Foundation for the support of one student.

\section{SAMPLE DESCRIPTIONS}

I. ARCHAEOLOGIC SAMPLES

1. Cyprus

\section{A. Mediterranean}

\section{Phaneromeni series}

Middle Cypriote Bronze age settlement site located at Phaneromeni (Episkopi), Limassol Dist, Cyprus $\left(34^{\circ} 40^{\prime} \mathrm{N}, 32^{\circ} 55^{\prime} \mathrm{E}\right)$. Coll and subm 1975 by J R Carpenter, Dept Romance Languages \& Classics, Kent State Univ, Kent, Ohio (Weinberg, 1956).

General Comment: samples expected to be contemporaneous with each other.

\section{P.2386. Sample 1}

$3720 \pm 70$

Charcoal, Sample 1, from Operation A6, Lot 5 (Excavator's 75-2). Sample from beside house wall, but underlying stones from its collapse, ca $1.05 \mathrm{~m}$ below surface.

\section{P-2387. Sample 3}

$3620 \pm 60$ 75-3). Sample from beside house wall, but underlying stones from its collapse, ca $1.05 \mathrm{~m}$ below surface.

\section{P-2388. Sample 2}

$3520 \pm 70$ $* 2040 \pm 70 \mathrm{BC}$

Charcoal, Sample 2, from Operation A13, Lot 6 (Excavator's Ref Ph 75-6). Possibly hearth or fire pit, near house wall, covered by collapsed stones, ca $1.27 \mathrm{~m}$ below surface.

\section{Greece}

\section{P-2101. Athenian Agora}

$2390 \pm 40$

$* 490 \pm 50 \mathrm{BC}$

Wood (Deposit J5:1) from public well at NW corner of Agora Sq, Athens, Greece $\left(38^{\circ} 00^{\prime} \mathrm{N}, 23^{\circ} 44^{\prime} \mathrm{E}\right)$. Sample from layer dating to 1 st half of 2nd century вс. Coll 1971 and subm by T L Shear, Dir, Agora Excavations, Am School Classical Studies at Athens. Well in use from late 5 th century BC through Hellenistic period and partially reopened in 10th century AD (Shear, 1973, p 130-134).

\section{Franchthi Cave series}

Franchthi cave $\left(37^{\circ} 26^{\prime} \mathrm{N}, 23^{\circ} 8^{\prime} \mathrm{E}\right)$ is near $\mathrm{W}$ tip of high, rugged headland, directly across from village of Koilada near Porto Cheli in $S$ Argolid, Peloponnese, Greece. Site is especially important for its apparent 
continuous stratified sequence from Late Paleolithic through Mesolithic and the critical transition to Neolithic. There are no stratified prehistoric remains later than Late Neolithic. Samples coll and subm 1974 by T W Jacobsen, Indiana Univ, Bloomington, Indiana (1968; 1969a, b, c; 1973a, b; 1974; 1976). For additional dates for this site, see R, 1971, v. 13, p 364367; R, 1974, v 16, p 220-221; R, 1975, v 17, p 201-203.

\section{P-2227. F/A Balk, Unit 195S}

$9430 \pm 160$

Carbonized matter from F/A Balk, Unit 195S, dark reddish occupation layer, 7.62m depth (max). Below P-2108, $9250 \pm 120$ (R, 1975, v 17, p 203). Date expected to be Mesolithic. Comment: date calculated with 5730 half-life, but not corrected $=7760 \pm 160 \mathrm{Bc}$.

\section{P-2228. F/A Balk, Unit $195 S$}

$9060 \pm 110$

Carbonized matter from F/A Balk, Unit 195S, 7.62 depth, below P-2108, $9250 \pm 120(\mathrm{R}, 1975, \mathrm{v} 17, \mathrm{p} 203)$. Sample coll by flotation in water sieving device using mixture of fresh and sea water (Jacobsen, 1973, p 57; French, 1971). Date expected to be Mesolithic and comparable to P-2227 (above). Comment: $\mathrm{NaOH}$ pretreatment. Date calculated with 5730 half-life, but not corrected $=7380 \pm 110$ BC.

\section{P.2229. F/A Balk, Unit 197S}

$9210 \pm 110$

Charred bone and other carbonized material from F/A Balk, Unit $197 \mathrm{~S}$, ash lens in dark reddish occupation layer, $7.76 \mathrm{~m}$ depth (max). Below P-2227 and -2228, above. Date expected to be early Mesolithic. Comment: date calculated with 5730 half-life, but not corrected $=7530 \pm$ 110 BC.

P-2230. F/A Balk, Unit 197S

$9280 \pm 110$

Carbonized matter from F/A Balk, Unit 197S, 7.76m depth (max), below P-2227 and -2228, above. Sample coll by flotation in water-sieving device (see above). Date expected to be Mesolithic and comparable to P-2229, above. Comment: date calculated with 5730 half-life, but not corrected $=7610 \pm 110$ вс.

\section{P-2231. F/A Balk, Unit 204S}

$$
10,260 \pm 110
$$

Charcoal and soil from F/A Balk, Unit 204S, red clay deposit with evidence of human occupation, $8.27 \mathrm{~m}$ depth (max). Below P-2229 and -2230, above. Date expected to be Upper Paleolithic. Comment: date calculated with 5730 half-life, but not corrected $=8620 \pm 110$ BC.

\section{P.2232. F/A Balk, Unit 207S}

$$
\mathbf{1 0 , 8 4 0} \pm \mathbf{5 1 0}
$$

Soil and charcoal from F/A Balk, Unit 207S, near base of red clay deposit above rockfall layer, $8.52 \mathrm{~m}$ depth (max). Below P-2231, above. Date expected to be Upper Paleolithic. Comment: sample counted in small counter. Date calculated with 5730 half-life, but not corrected $=$ $9210 \pm 520$ вс. 


\section{P-2233. H-1, Quad B, Unit 191-192}

$21,480 \pm 350$

Soil and carbonized matter from H-1, Quad B, Unit 191-192, redbrown clay matrix with considerable angular gravels, $6.31 \mathrm{~m}$ depth (max). Sample stratigraphically between 2 earliest dates from site, P-1827, 12,540 $\pm 180(\mathrm{R}, 1974, \mathrm{v} 16, \mathrm{p} 221)$ and $\mathrm{I}-6140,22,330 \pm 1270(\mathrm{R}, 1976, \mathrm{v} 18$, p 187). Date expected to be Upper Paleolithic. Comment: date calculated with 5730 half-life, but not corrected $=20,170 \pm 360$ вс.

\section{P-2234. F/F1 (W scarp)}

$6830 \pm 60$

Soil and charcoal from F/F1 (W scarp), near top of grayish occupation layer at 3.30 to $3.40 \mathrm{~m}$ depth. Date expected to be Middle Neolithic, slightly later than P-1922-A, $6730 \pm 70$ (R, 1974, v 16, p 221). Date calculated with 5730 half-life, but not corrected $=5070 \pm 70$ BC.

P-2235. F/F1 ( W scarp)

$6750 \pm 80$

Soil and charcoal from F/F1 (W scarp), near base of moderate brown 
P-1601. Akrotiri, Trench Arvaniti 3

$3380 \pm 60$

Charcoal (Olea $s p$ ) id by B F Kukachka, Forest Prod Lab, US Dept Agric, Madison, Wisc. From erosion soil at base of $6 \mathrm{~m}$ trench in pure Middle Cycladic II-Late Cycladic I context. Coll and subm 1968 by Emily Vermeule, Mus Fine Arts, Boston. Expected date from pottery, 14701540 BC. Comment (EV): should be at least 200 yr later than P-303, 3520 \pm 50 from Lerna $V$ (Kohler and Ralph, 1961, p 365). Date expected to be comparable to L-362, $3370 \pm 100(\mathrm{R}, 1959$, v 1, p 20) (Galanopoulos, 1958; Marinatos, 1968).

P-1602. Akrotiri, Trench Arvaniti 3

$3420 \pm 40$ *1870. 1760. $1720 \pm 40 \mathrm{BC}$ 
P-1891. Akrotiri, AK-18

$3480 \pm 70$

Charcoal, probably from shrubs id B F Kukachka, from pit dug for modern roof pillar No 11 within Structure Beta. Coll 1969 by Spyridon Marinatos, subm 1971 by Christos Doumas.

\section{P-1893. Akrotiri, AK-19}

$3990 \pm 70$

$* 2600 \pm 70 \mathrm{BC}$

Charcoal (Pinus $s p$ ) id B F Kukachka from area $\mathrm{E}$ of $\mathrm{Rm} 4$ in structure Delta. Coll 1970 by Spyridon Marinatos, subm 1971 by Christos Doumas.

\section{P-1894. Akrotiri, AK-20}

$3310 \pm 70$

$* 1680 \pm 70 \mathrm{BC}$

Charcoal, probably from shrubs, id B F Kukachka, from Rm 3 of Structure Delta, under paved floor. Coll 1970 by Spyridon Marinatos, subm 1971 by Christos Doumas. Comment: NaOH pretreatment.

\section{P-1895. Akrotiri, AK-17}

$3320 \pm 50$

$* 1690 \pm 50 \mathrm{BC}$

Charcoal, probably from shrubs, id B F Kukachka, from pit dug for modern pillar No 2, within Structure Beta, destruction level. Coll 1969 by Spyridon Marinatos, subm by Christos Doumas.

\section{P-1619. Akrotiri, Bronos Bridge}

$2990 \pm 70$ and subm by Spyridon Marinatos. Comment: sample undersized; counted by Isotopes (I-4442) and was undersized in their counter ( $76 \%$ filling).

\section{P-1892. Akrotiri, Bronos Bridge, A-16}

$$
\mathbf{3 3 3 0} \pm \mathbf{5 0}
$$

$* 1690 \pm 50 \mathrm{BC}$

Charcoal, probably from shrubs, id B F Kukachka, from Area 6 of Bronos Bridge, destruction level. Coll 1969 by Spyridon Marinatos and subm by Christos Doumas. Comment: $\mathrm{NaOH}$ pretreatment.

\section{P-1697. Boudouroglou Mine}

$$
\begin{array}{r}
3070 \pm 60 \\
* 1450-1400 \pm 60 \mathrm{BC} \\
\delta^{1 s} C_{w}=+0.9 \% 0
\end{array}
$$

Carbonized beans, possibly "fava", from mining installation of Boudouroglou and Co, between villages of Akrotiri and Moghalochai. Sample related to expansion of Minoan culture on Thera. Sample from brink of precipitous side of caldera. Found in large jug underneath lower volcanic layer of pumice. Coll by Spyridon Marinatos, subm 1968 by Christos Doumas. 
3. Italy

P-2403. Nuraghe Genna Maria,

Sample 5, charcoal from Hut 17, S corner, $110 \mathrm{~cm}$ depth at Bronze age or Early Iron age site of Nuraghe Genna Maria, Villanovaforru (Cagliari) Sardinia, Italy $\left(38^{\circ} 38^{\prime} \mathrm{N}, 8^{\circ} 50^{\prime} \mathrm{E}\right)$. Coll 1975 by Enrico Atzeni, subm by M S Balmuth, Tufts Univ, Massachusetts (Atzeni, 1972).

\section{Ortu Comidu, Sardara, series}

Complex of stone structures at Ortu Comidu, Sardara (Cagliari), Sardinia, Italy $\left(38^{\circ} 36^{\prime} \mathrm{N}, 8^{\circ} 50^{\prime} \mathrm{E}\right)$. Area M produced Nuraghic (8th century BC and earlier) and Punic (6th century BC and later) material. Area N produced Nuraghic material only. Coll 1975 and subm by M S Balmuth, Tufts Univ, and Patricia Phillips, Sheffield Univ, England.

P-2399. Sample 1, Area N, 3

$2910 \pm 250$

Charcoal from 30 to $40 \mathrm{~cm}$ depth. Comment: sample counted in small counter.

P-2400. Sample 2, Area N, 4, 5, 7

$2910 \pm 220$

Charcoal from 40 to $79 \mathrm{~cm}$ depth. Comment: sample counted in smal counter.

$* 1190-1170 \pm 220 \mathrm{BC}$

\section{P-2401. Sample 3, Area M}

$3080 \pm 60$

Charcoal from 40 to $50 \mathrm{~cm}$ depth. Comment: $\mathrm{NaOH}$ pretreatment.

\section{P-2402. Sample 4, Area $M$}

$$
2970 \pm 50
$$

Charcoal from 40 to $50 \mathrm{~cm}$ depth. Comment: $\mathrm{NaOH}$ pretreatment.

\section{B. Near East}

\section{Egypt}

Most of the following Egyptian samples are closely dated on archaeol or other grounds, and so form a control series of known-age samples against which corrected ${ }^{14} \mathrm{C}$ dates may be compared. For further explanation, see Univ of Pennsylvania Dates XVI (R, 1974, v 16, no 2, p 198-218); Ralph and Michael, 1967, p 3-11; 1970, p 109-118; and Ralph et al, 1973. Only samples P-1883 and -2337 are exceptions, both being from mummies for which independent assessments of date were unavailable. These Pennsylvania known-age samples constitute part of larger, ongoing MASCA study by H N Michael (HNM), Univ Mus, Univ Penna, Philadelphia and James Weinstein (JW), Univ Mus. This study (ms in preparation) includes analyses of 233 radiocarbon dates, obtained by various labs, of Egyptian dynastic materials. 
Where possible, deviant radiocarbon dates have been explained, although subtle errors in assigning archaeol provenance cannot be assessed. Attention must be paid to the special nature of deviant dates derived from some of the halfa grass samples, below (Lucas, 1962, p 129, 131; Täckholm, 1956, p 521; Greiss 1957, p 5-30). Comparisons between radiocarbon dates of wood, charcoal, and grass samples derived from the same structures suggest that grasses growing in or close to the Nile or its previous flood waters may have acquired some older carbon from watersoluble carbonates, and may thus have become unsuitable for ${ }^{14} \mathrm{C}$ dating.

All hist dates used below are based upon the chronology of the 3rd ed of the Cambridge Ancient History (Hayes, 1970, p 173-193).

\section{P.1883. PUM I}

$2630 \pm 50$

$* \mathbf{8 4 0 - 8 2 0} \pm 50$ BC

$\delta^{13} C_{w}=-2.93 \%$

Linen wrappings from Univ Mus mummy PUM I (E 2813 A 4), of unknown provenance and date. Donated 1905 by John Wanamaker. Subm 1972 by $\mathrm{H}$ N Michael, following mummy's autopsy.

\section{P.2337. ROM II \\ $* 1870-1720+60$ \\ $\delta^{13} C_{w}=+4.56 \%$ o}

Human tissue consisting of tongue and some attached skeletal muscle from well-preserved mummified head of unknown provenance. Coll 1910 in Egypt by Trick Corelli, founder, Royal Ontario Mus, Toronto. Subm May 1975, by Patrick Horne, Dept Histopathol, Toronto Gen Hospital, Banting Inst, Toronto. Comments: sample pyrolized in $\mathrm{N}_{2}$ before normal acid treatment. $(\mathrm{PH})$ : X-ray and exam of histologic sec of left temporal bone of this specimen revealed evidence of middle ear disease and mastoiditis, never before shown in such ancient material.

\section{P-1831. Nebhepetre Mentuhotep, Dynasty XI $* 1290 \pm 70$ BC}

Fragments of triangular loaves of bread (Ac No 25.3.230-235) from Metropolitan Mus Art, New York, excavations of Dynasty XI, ca 21331991 BC, temple of Nebhepetre Mentuhotep (Winlock, 1924, p 10, fig 6), located at Deir el Bahri on W side of Nile, Egypt (25 $\left.40^{\prime} \mathrm{N}, 32^{\circ} 30^{\prime} \mathrm{E}\right)$. Sample from original temple axis in sealed foundation deposits between N postern and temple grove. Subm 1971 by $\mathrm{H}$ N Michael. Comment: anomalous date evidently explained when sample was found to be impregnated with insect frass, as well as fumigated in 1959 with ethylene oxide and $\mathrm{CO}_{2}$ while in mus storage.

\section{P-1821. Sesostris III, Dynasty XII}

$3600 \pm 70$

Outside rings of wood sample from cedar deck plank of funerary boat of Sesostris III (ca 1878-1843 BC), found at Dashur, Egypt $\left(29^{\circ} 48^{\prime} \mathrm{N}, 31^{\circ}\right.$ 13' E). Coll 1969 by James VanStone, Chicago Mus Nat Hist; subm 1971 by H N Michael. Comment (HNM \& JW): date is archaeol consistent, given age of cedar wood. Other dates of samples from same boat plank 
show excellent inter-lab agreement; see C-18, $3620 \pm 180$ (Arnold and Libby, 1951, p 111); GrN-1157, $3550 \pm 60$; GrN-1178, $3610 \pm 50$ (de Vries and Waterbolk, 1958, p 1555; Deevey et al, 1967, p 36); BM-22, $3530 \pm$ 150 (R, 1959, v 1, p 83); UCLA-900, $3640 \pm 80$ (R, 1965, v 7, p 354); TF$564,3570 \pm 80(\mathrm{R}, 1975, \mathrm{v} 17, \mathrm{p} 221)$; UCR-126, $3750 \pm 110(\mathrm{R}, 1975$, v 17, p 404).

\section{P-1830. Puhorsenbu, Dynasty XVII}

Wood, id as Ficus sycamorus by B F Kukachka, Forest Prod Lab, US Dept Agric, Madison, Wisconsin, from a Rishi type coffin found in 1918 by Metropolitan Mus at Assasif, E of Pabasa, Egypt $\left(25^{\circ} 40^{\prime} \mathrm{N}, 32^{\circ} 30^{\prime} \mathrm{E}\right)$. From Burial 6A X B44, Field No. 30104, Exped Negative Nos 6A 156-7, 204 M11G 118,124 (Hayes, 1959, p 31). Dated to period of Dynasty XVII (ca 1650-1567 BC). Subm 1971 by H N Michael. Comment: date slightly young, although coffin, on stylistic grounds, could date to earliest Dynasty XVIII. Sample taken from outermost (youngest) rings of hollowed out sycamore log used as coffin.

\section{P-1828. Ahmose, Dynasty XVIII}

$3310 \pm 70$

$* 1680 \pm 70 \mathrm{BC}$

$\delta^{13} C_{w}=-4.78 \%$

Wood id as Ficus sycamorus (B F Kukachka) from coffin of Ahmose (Metropolitan Mus no. 12.181.298) found at Dra Abu el-Naga, opposite

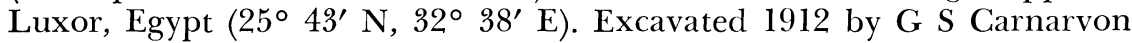
for Metropolitan Mus of Art, New York, and independently dated to early Dynasty XVIII, ca 1567-1500 BG (Carnarvon and Carter, 1912, P1 LXII, fig 2, LVIII, fig 2, and p 84, paragraph 73, Hayes 1935, p 80-81, footnote 34, p 91, p 134, fig 23). Subm 1971 by $\mathrm{H}$ N Michael. Comment: date consistent with archaeol expectations, given $100 \mathrm{yr}$ maximum estimated life-time for sycamore tree.

\section{Malkata series}

Malkata, palace-settlement of Amenhotep III (reigned ca 1417-1379 BC), near Gurna, opposite Luxor, on W bank of Nile, Egypt $\left(25^{\circ} 43^{\prime} \mathrm{N}\right.$, $\left.32^{\circ} 38^{\prime} \mathrm{E}\right)$. Presumed to be single period site relating to Amenhotep III's ambitious residential constructions and the possible interests of his immediate successors. Site is, however, immediately adjacent to a variety of both earlier and later monumental structures. Samples coll March 1973, subm 1973 by E K Ralph, Univ Penna, Phila, and Barry Kemp, Cambridge Univ, Cambridge, England.

General Comment: samples from sealed deposits, and believed contemporary with each other and later part of Dynasty XVIII (ca 1420-1320 BC).

\section{P-1997. Malkata M73/J/ba 40,} Dynasty XVIII

$$
\begin{array}{r}
2980 \pm 50 \\
* 1300-1270 \pm 50 \mathrm{BC} \\
\delta^{13} C_{w}=0.00 \% \text { o }
\end{array}
$$

Charcoal in mud from Level 2. Comment: this late Dynasty XVIII date consistent with archaeol expectations. 
$3180 \pm 50$

P-2043. Malkata Site K, Dynasty XVIII $* 1540,1510 \pm 50$ вC

$\delta^{13} C_{w}=+12.40 \%$

Halfa grass from walls of Trench ag 11-al 11, portion of roofing of mudbrick bldg, undisturbed since its demolition in late Dynasty XVIII. Comment (HNM-JW): this anomalous date unexplained; perhaps due to dating problems peculiar to grasses.

P-2042. Malkata Site K, Dynasty XVIII $* 1370,1340 \pm 60$ BC $\delta^{13} C_{w}=+11.51 \%$ o

All particulars as P-2043 (above). Comment (HNM-JW): date meets archaeol criterion.

\section{Horemheb series}

\section{P-2111. Horemheb, Dynasty XVIII}

$$
\begin{array}{r}
3400 \pm 50 \\
* 1870-1720 \pm 50 \mathrm{BC} \\
\delta^{13} C_{w}=+3.15 \%
\end{array}
$$

Fragment, apparently sycamore, from composite wooden statue presently in Cairo Mus, Cairo (P-12 W3 Jour No. 46888). Found in cliff tomb of Horemheb (reigned ca 1348-1320 BC) in Valley of the Kings on W bank of Nile, opposite Luxor, Egypt $\left(25^{\circ} 40^{\prime} \mathrm{N}, 32^{\circ} 30^{\prime} \mathrm{E}\right)$ (Daressy, 1912, p 107, no. 7). Coll 1973, by Henri Riad, Dir, Cairo Mus; subm 1973 by H N Michael. Comment (HNM-JW): even allowing for maximum age of 100 yr for sycamore, this date is deviant by over $200 \mathrm{yr}$, and remains unexplained.

\section{P-2112. Horemheb, Dynasty XVIII}

$$
\begin{array}{r}
3190 \pm \mathbf{5 0} \\
* 1560-1520 \pm \mathbf{5 0} \mathbf{~ B C} \\
\delta^{13} C_{w}=+2.78 \% \text { 作 }
\end{array}
$$

Wood, otherwise unid, from wedge binding sandstone blocks in Ninth Pylon of Temple of Amun, on E bank of Nile, Egypt $\left(25^{\circ} 43^{\prime} \mathrm{N}\right.$, $32^{\circ} 39^{\prime} \mathrm{E}$ ). Pylon apparently built by Horemheb (reigned ca 1348-1320 BC). Coll 1971 by Zaki Iskander, Org Egyptian Antiquities, Cairo. Subm by $\mathrm{H}$ N Michael. Comment: date not inconsistent with Dynasty XVIII construction. For other date for sample from same structure, see CRCA-5, $2162 \pm 100(\mathrm{R}, 1974, \mathrm{v} 16, \mathrm{p} 2)$. Another CRCA date for portion of same sample, $3310 \pm 100$ (personal commun from $\mathrm{S}$ M Nakhla to $\mathrm{H} \mathrm{N}$ Michael).

\section{P-1996. Horemheb, Dynasty XVIII}

$$
\begin{array}{r}
3230 \pm 50 \\
* 1600-1570 \pm \mathbf{5 0} \mathbf{~ B C} \\
\delta^{13} C_{w}=+7.48 \% o
\end{array}
$$

Charcoal inclusions, perhaps Acacia, from mudbricks constituting Second Pylon of small temple $\mathbf{N}$ of Dynasty XX temple of Medinet Habu, on W bank of Nile, opposite Luxor (25 $\left.47^{\prime} \mathrm{N}, 32^{\circ} 39^{\prime} \mathrm{E}\right)$. Second Pylon built in late Dynasty XVIII by Horemheb (reigned ca 1348-1320 BC), last king of Dynasty (Hölscher, 1934, pl 33). Coll March 1973 by Barry Kemp and E K Ralph, subm 1973 by Barry Kemp. Comment 
(HNM-JW): date somewhat earlier than expected, likely due to age of wood when burned.

\section{Dra Abu el-Naga series}

Dra Abu el-Naga S, on W bank of Nile opposite Luxor, Egypt, constitutes a portion of the vast Theban necropolis $\left(25^{\circ} 43^{\prime} \mathrm{N}, 32^{\circ} 38^{\prime} \mathrm{E}\right)$. Samples taken from pyramidal tomb superstructures, built of courses of mud brick separated by beddings of halfa grass, with occasional use of timber reinforcement. Unless otherwise specified, coll and subm 1970 by Lanny Bell, Univ Mus, Univ Penna.

General Comment (LB): "Primary" describes sample taken farthest from surface layers of pyramid, with the least chance of disturbance by human activity; "Secondary" describes sample taken closer to the pyramid surface; "Tertiary" describes sample taken from pyramid surface, thus most likely to have been disturbed. Tentative known dates for owners of tombs are:

1. Nebwenenef (Tomb 157), maximum tenure as High Priest of Amun, yrs 1-17 of Ramses II, = ca 1304-1287 BC (Kees, 1953, p 118).

2. Nakhtmin (Tomb 282), attested as Chief of Bowmen of Kush within 1st 2/3 of reign of Ramses II, = са 1304-1260 вс (Habachi, 1968, p 111, Seele, 1959, p 7-9, and Lefebvre, 1929b, p 264).

3. Bekenkhons I (Tomb 35), maximum tenure as High Priest of Amun, later in reign of Ramses II, = са 1264-1237 вG (PlantikowMünster, 1969, p 126-127).

4. Roma-Roy (Tomb 283), maximum tenure as High Priest of Amun, late in reign of Ramses II into reign of Seti II, = ca 1250-1210 BC (Lefebvre, 1929a, p 3-4, 23-24; 1929b, p 254).

5. Tjanefer (Tomb 158), attested in reign of Ramses III, = ca 1198-1166 вс (Habachi, 1968, p 111, Seele, 1959, p 7-9, and Lefebvre, 1929b, p 264).

\section{Nebwenenef series}

\section{P-1730. Nebwenenef, Dynasty XIX}

$3120 \pm 50$

$* \mathbf{1 4 8 0} \pm \mathbf{5 0} \mathrm{BC}$

$\delta^{13} C_{w}=+6.6 \%$

Portion of palm rachis (Phoenix dactylifera) id by D F Cutler, Jodrell Lab, Royal Bot Gardens, Surrey, England. Primary sample from pyramid of Nebwenenef. Comment: unexplained anomalous date suggested dating of 2nd portion (P-1730-A, below).

\section{P-1730-A. Nebwenenef, Dynasty XIX}

Portion of P-1730 (above). Comment: this anomalous date remains unexplained. 


\section{P.1731. Nebwenenef, Dynasty XIX $* 1360,1330-1300 \pm 60 \mathrm{BC}$

$$
\delta^{13} C_{w}=+14.56 \%
$$

Halfa grass, (?) (Desmostachya bipinnata) id by D F Cutler. Secondary sample from pyramid of Nebwenenef. Comment: date consistent with archaeol expectations.

\section{P-1732. Nebwenenef, Dynasty XIX}

$$
\begin{array}{r}
3030 \pm 60 \\
* 1370,1340 \pm 60 \mathrm{BC} \\
\delta^{13} C_{v}=+13.8 \% o
\end{array}
$$

Halfa grass, (?) (Desmostachya bipinnata) id by D F Cutler. Tertiary sample from pyramid of Nebwenenef. Comment: date consistent with archaeol expectations.

\section{P-1825. Nebwenenef, Dynasty XIX}

$$
2940 \pm 50
$$

$* 1240-1220 \pm 50 \mathrm{BC}$

$$
\delta^{13} C_{w}=+7.65 \%
$$

Halfa grass, (?) (Desmostachya bipinnata) id by D F Cutler. Secondary sample from pyramid of Nebwenenef. Comment: portion of British Mus sample BM-658b. Consistent with archaeol expectations.

\section{Nakhtmin series}

\section{P-1733. Nakhtmin, Dynasty XIX}

$$
\begin{array}{r}
2920 \pm 50 \\
* 1210-1190 \pm \mathbf{5 0} \mathrm{BC} \\
\delta^{13} C_{w}=+21.8 \%
\end{array}
$$

Halfa grass, (?) (Desmostachya bipinnata) id by D F Cutler. Primary sample from within pyramid of Nakhtmin. Comment: date consistent with archaeol expectations.

\section{P-1734. Nakhtmin, Dynasty XIX} $3400 \pm 60$
$70 \pm 60 \mathrm{BC}$ $\delta^{13} C_{w}=+17.43 \%$ o

Halfa grass, (?) (Desmostachya bipinnata) id by D F Cutler. Secondary sample from pyramid of Nakhtmin. Comment: unexplained anomalous date sugqested dating of 2nd portion (P-1734-A. below). 


\section{P-1739-A. Bekenkhons I, Dynasty XIX $\quad *_{A D} 290-320 \pm 50$ \\ $\delta^{1 s} C_{w}=+24.3 \%$}

Halfa grass, (?) (Desmostachya bipinnata) id by D F Cutler. Primary sample from pyramid of Bekenkhons I. Comment (LB): evidently taken from intrusive Late Roman wall within pyramid.

\section{P-1740. Bekenkhons I, Dynasty XIX}

$$
\begin{array}{r}
3000 \pm 60 \\
* 1300 \pm 60 \mathrm{BC} \\
\delta^{1 s} C_{w}=+6.66 \%
\end{array}
$$

Halfa grass, (?) (Desmostachya bipinnata) id by D F Cutler. Secondary sample taken from pyramid of Bekenkhons I. Comment: date consistent with archaeol expectations.

\section{Roma-Roy series}

\section{P-1735. Roma-Roy, Dynasty XIX}

$$
\begin{array}{r}
3130 \pm 40 \\
* 1490 \pm 40 \mathrm{BC} \\
\delta^{1 s} C_{w}=+16.1 \% o
\end{array}
$$

Halfa grass, (?) (Desmostachya bipinnata) id by D F Cutler. Primary sample from pyramid of Roma-Roy. Comment: date older than expected.

\section{P-1736. Roma-Roy, Dynasty XIX}

$3280 \pm 50$

$* 1650 \pm 50 \mathrm{BC}$

$\delta^{13} C_{w}=+19.11 \%$

Halfa grass, (?) (Desmostachya bipinnata) id by D F Cutler. Secondary sample from pyramid of Roma-Roy. Comment: anomalous date unexplained.

\section{P-1737. Roma-Roy, Dynasty XIX}

$$
3120 \pm 50
$$

$* 1480 \pm 50 \mathrm{BC}$ $\delta^{13} C_{w}=0.00 \%$ 
Tjanefer series

\section{P-1696. Tjanefer, Dynasty XX}

$$
\begin{array}{r}
3080 \pm 60 \\
* 1450-1400 \pm 60 \mathrm{BC} \\
\delta^{13} C_{w}=+12.3 \% o
\end{array}
$$

Halfa grass (Desmostachya bipinnata) id by D F Cutler. Primary sample from pyramid of Tjanefer. Comment: date older than expected. Previous dates for samples from this pyramid BM-336, $2890 \pm 100 ;-337,3080$ $\pm 75(\mathrm{R}, 1971, \mathrm{v} 13, \mathrm{p} 162)$; UCLA-1393, $3060 \pm 60$; and $-1394,3030$ \pm 60 (Berger, 1970, p 28).

\section{P-1698. Tjanefer, Dynasty XX}

$$
\begin{array}{r}
2990 \pm \mathbf{5 0} \\
* 1290 \pm \mathbf{5 0} \mathbf{B C} \\
\delta^{1 s} C_{w}=+12.3 \% o
\end{array}
$$

Halfa grass (Desmostachya bipinnata) id by D F Cutler. Primary sample from pyramid of Tjanefer. Comment: date older than expected.

\section{P.1699. Tjanefer, Dynasty XX}

$$
\begin{array}{r}
* 1360-1300 \pm 50 \mathrm{BC} \\
\boldsymbol{\delta}^{13} C_{w}=0.00 \% \text { o }
\end{array}
$$

Wood (Acacia) id by B F Kukachka, sawn from branch protruding from pyramid of Tjanefer. Comment: date consistent with archaeol expectations, when probable age of wood is considered.

\section{Medinet Habu series}

Medinet Habu, on W bank of Nile, opposite Luxor, Egypt $\left(25^{\circ} 47^{\prime}\right.$ $\mathrm{N}, 32^{\circ} 39^{\prime} \mathrm{E}$ ), is portion of Theban necropolis area in which Dra Abu el-Naga, Deir el-Bahri, and Malkata are also located. Medinet Habu is dominated by monumental funerary temple and appended palace of Ramses III (reigned ca 1198-1166 BC); earlier and later structures are also within temple complex; these include Dynasty XXI House of Butehamon from which Sample P-1994, below, was taken. Girdle wall surrounding temple was subject to Dynasty XXI (ca 1085-945 BC), Coptic, and postCoptic alterations and rebuildings.

\section{P-1819. Medinet Habu, Dynasty XX}

$$
\begin{array}{r}
960 \pm 100 \\
* \text { AD } 1020 \pm 100 \\
\delta^{13} C_{w}=-3.83 \% 0
\end{array}
$$

Halfa grass, constituting part of the bonding between mud-brick courses of upper part of $\mathrm{N}$ enclosure wall of temple. Coll and subm 1971 by $\mathrm{H}$ N Michael. Comment (HNM-JW): sample evidently from postCoptic additions to the wall.

\section{P-1820. Medinet Habu, Dynasty XX}

$$
\begin{array}{r}
1110 \pm \mathbf{5 0} \\
*_{\mathbf{A D} 860-880} \pm \mathbf{5 0} \\
\delta^{13} C_{w}=+8.6 \%
\end{array}
$$

Macerated straw from straw-dung bonding material between courses of upper part of S enclosure wall of temple. Coll 1971 and subm 1971 by H N Michael. Comment (HNM-JW): evidently from post-Coptic additions to wall. 


\section{P-1995. Medinet Habu, Dynasty XX}

$2810 \pm 50$
$* 1050-1020 \pm 50 \mathrm{BC}$

$\delta^{13} C_{w}=+5.55 \%$ o

Charcoal fragments (Pistacea) id by R C Koeppen, Forest Prod Lab, US Dept Agric, Madison, Wisconsin. Found as inclusions in N, W, and S inner enclosure walls of temple. Taken from ground level to height of 2m. Coll 1973 by Barry Kemp and E K Ralph; subm 1973 by E K Ralph. Expected date Dynasty XXI (ca 1085-945 BC). Comment: this mid-Dynasty XXI date consistent with archaeol expectations.

\section{P-1994. House of Butehamon, Dynasty XXI}

$$
\begin{array}{r}
3150 \pm 40 \\
* 1510 \pm 40 \mathrm{BC} \\
\delta^{13} C_{w}=+8.33 \%
\end{array}
$$

Charcoal fragments, palm wood, id by R C Koeppen. Found as inclusions in mud-brick walls of reception $\mathrm{rm}$ of House of Butehamon. Coll 1973 by Barry Kemp and E K Ralph; subm 1973 by E K Ralph. Expected date during reign of Pinudjem I, early Dynasty XXI (ca 1050 BC). Comment (HNM-JW): since charcoal is from relatively short-lived palm wood, reconciliation of 500-yr deviance cannot be made.

\section{P-1955. Faya, Dynasty XXI}

$$
\begin{array}{r}
2890 \pm 40 \\
* 1180-1160 \pm 40 \mathrm{BC} \\
\delta^{13} C_{w}=-0.97 \% o
\end{array}
$$

Wood (Salix) id by R C Koeppen, from coffin lid of Lady Faya, now in Chicago Mus Nat Hist (Cat No. 31840). Of unknown provenance, independently dated to period of Dynasty XXI (ca 1085-945 BC). Coll 1973 and subm 1973 by $\mathrm{H}$ N Michael. Comment (HNM-JW): Dynasty XX date for wood consistent with construction of coffin lid in Dynasty XXI.

\section{P-1956. Faya, Dynasty XXI}

$2980 \pm 60$

$* 1300-1270 \pm 70 \mathrm{BC}$ $\delta^{13} C_{w}=-0.77 \%$

Wood (Ficus) id by R C Koeppen, from coffin of Lady Faya. Subm 1973 by H N Michael. Comments: see P-1955, above. (HNM-JW): Dynasty XIX date for wood not inconsistent with Dynasty XXI date for construction of coffin.

\section{Pasebakhaienipet series}

Of unknown provenance, but probably from Deir el-Bahri $\left(25^{\circ} 43^{\prime}\right.$ $\mathrm{N}, 32^{\circ} 38^{\prime} \mathrm{E}$ ), coffin and wrapped mummy of Pasebakhaienipet were acquired by Brooklyn Mus, New York (Brooklyn Mus 08.480 la-b). Assemblage was independently dated to period of Dynasty XXI (ca 1085-945 BC). Subm 1971 by $\mathrm{H}$ N Michael.

General Comment (HNM-JW): Pasebakhaienipet dates confirm re-use of older materials. The coffin is a composite one, the sides and bottom of sycamore are held in place by much older slabs of appropriately slotted cedar wood. 


\section{P-1816. Pasebakhaienipet, Dynasty XXI}

$2730 \pm 50$

$* 930 \pm 50$ BC

$\delta^{13} C_{v}=-1.9 \%$ o

Wood chips (Ficus sycamorus) id by B F Kukachka, from bottom of coffin of Pasebakhaienipet. Comment: sample derived from outer rings of sycamore, and consistent with construction of coffin in Dynasty XXI.

\section{P-1817. Pasebakhaienipet, Dynasty XXI}

$3780 \pm 50$ $* 2190 \pm 60 \mathrm{BC}$ $\delta^{13} C_{w}=+1.83 \%$

Wood chips (Cedrus libani) id by B F Kukachka, from joint between side and bottom of coffin of Pasebakhaienipet. Comment: excessive age of wood highly suggestive of its re-use, especially in view of reduced Egyptian access to sources of cedar during this period, and unusually intensive Dynasty XXI re-use of other materials.

\section{P-1818. Pasebakhaienipet, Dynasty XXI}

$$
\begin{array}{r}
2790 \pm 60 \\
* 1010 \pm 60 \mathrm{BC} \\
\delta^{13} C_{w}=-0.91 \% o
\end{array}
$$

Linen wrappings from mummy of Pasebakhaienipet. Comment: consistent with archaeol expectations. This short-lived sample should provide best evidence for actual date of burial.

\section{Djedmutesankh series}

Coffin and wrapped mummy of Djedmutesankh (Cat No. 25.3.2 A-B) were excavated by Metropolitan Mus Art, New York, in Tomb 60, Chamber No. 5 at Deir el-Bahri $\left(25^{\circ} 43^{\prime} \mathrm{N}, 32^{\circ} 38^{\prime} \mathrm{E}\right)$, on W side of Nile, opposite Luxor, Egypt (Winlock, 1924, p 24-28, figs 28-29; 1926, p 19ff). Burial was dated independently to period of Dynasty XXI (ca 1085-945 BC). Subm 1973 by H N Michael. Comment (HNM-JW): this series may also show evidence of timber re-use, as with P-1817, above.

\section{P-1815. Djedmutesankh, Dynasty XXI}

$$
\begin{array}{r}
3550 \pm 50 \\
* 2070 \pm 60 \mathrm{BC} \\
\delta^{13} C_{w}=+0.91 \% o
\end{array}
$$

Wood (Gedrus libani) id by B F Kukachka, from inner coffin of Djedmutesankh (Field No. 25059, Exped Negative No. M6C 261-272). Comment (HNM-JW): date indicates cedar wood either from extremely old tree, or re-use.

\section{-1954. Djedmutesankh, Dynasty XXI $* 1240-1220 \pm 40$ BC $\delta^{13} C_{w}=+1.93 \%$}

Wood (Ficus sycamorus) id by B F Kukachka, from coffin lid of Lady Djedmutesankh (Chicago Mus Nat Hist Cat No. 30000). Comment: this Dynasty XIX-Dynasty XX date is inconsistent with late Dynasty XXI date for construction of coffin, especially in view of $100 \mathrm{yr}$ maximum estimated life-span for sycamore tree. Re-use therefore possible. 


\section{P-1871. Djedmutesankh, Dynasty XXI \\ $2690 \pm 50$ \\ $* 900 \pm 50 \mathrm{BC}$ \\ $\delta^{13} C_{w}=+2.88 \%$ o}

Linen wrappings from mummy of Lady Djedmutesankh. Comment: short-lived linen sample indicates a late Dynasty XXI-early Dynasty XXII date for actual burial.

\section{P-1884. PUM II, Ptolemaic-Roman}

$2020 \pm 50$

$* 200-170 \pm 50 \mathrm{BC}$

$\delta^{13} C_{w}=+13.67 \%$

Linen wrappings from Univ Mus mummy PUM II (L-55-15, 21-46-8, Negative nos. 31408, 31409, 73717, and 3481). Of unknown provenance, lent 1934 by Phila Mus Art. Dated to Graeco-Roman period by Henry Fischer, Metropolitan Mus Art, New York. Subm by H N Michael, following mummy's autopsy (Cockburn et al, 1975). Comment: date consistent with stylistic analysis.

2. Iran

\section{Qabr Sheykheyn series}

Samples from small mound of Qabr Sheykheyn, designated KS 168, in alluvial plain $30 \mathrm{~km} \mathrm{SE}$ of Dizful and $20 \mathrm{~km} \mathrm{NW}$ of Shushtar, Iran $\left(32^{\circ} 15^{\prime}\right.$ N, $48^{\circ} 45^{\prime}$ E). Coll 1970 and 1971 and subm by Harvey Weiss, Dept Near Eastern Languages \& Lit, Yale Univ, New Haven, Connecticut. Ceramic assemblage relatively uniform throughout all periods of occupation and most closely resembles Susiana $d$ (Le Breton, 1957). Uncorrected dates expected to be ca 4000-3500 вс (Weiss, 1972).

P-1936. K12, Lot 6, Str 3, Sample 3

Submitter's Sample 14, from K12, Lot 6, Str 3, Sample 3, carbonized reed matting from floor of central $\mathrm{rm}$ of Period II house. Comment: age quoted represents 2 standard deviations of uncertainty in counting of sample, background, and modern calibration sample. Probably contaminated with bitumen.

P-1937. K12/13, Lot 1, Str 2, Sample 1

Submitter's Sample No. 20, from K12/13, Lot 1, Str 2, 1, charcoal and wood from fill of Period II house, 7 to $10 \mathrm{~cm}$ below surface. Comment: see P-1936, above. Probably contaminated with bitumen.

\section{P-1938. M12, Lot 4}

$7810 \pm 120$

Submitter's Sample 21, from M12, Lot 4, charcoal on floor of IIIA occupation, near intrusive Islamic burial. Comment: possible bitumen contamination. Date calculated with 5730 half-life, but not corrected $=$ $6090 \pm 120$ BC.

\section{Shahr-i Sokhta series}

Shahr-i Sokhta is $59 \mathrm{~km}$ SSW of Zabol, Sistan prov, Iran $\left(30^{\circ} 44^{\prime} \mathrm{N}\right.$, $\left.61^{\circ} 30^{\prime} \mathrm{E}\right)$. Site displays a 4-period sequence (I-IV) distributed into 11 
phases $(0-10)$; Period I is oldest period, Phase 10 is oldest phase. Samples coll 1972, subm 1973 by Maurizio Tosi, Inst Itialiano per il Medio ed Estremo Oriente, Rome.

General Comment: basal date for Phase 10 TUNG-61, $4480 \pm 100$ (unpub) and latest date for Period IV TUNC-63, $3430 \pm 70$ (unpub). For other dates for Phase 3 see TUNC-21, $4065 \pm 65$; -22, $3829 \pm 61$; -23, 4082 $\pm 66 ;-24,3943 \pm 70 ;-25,4278 \pm 58 ;-26,4115 \pm 72 ;-27,3890 \pm 90(\mathrm{R}$, 1973, v 15, p 593-594). All bot id by R C Koeppen. In sample titles lst no. represents sec, 2nd no., cut, 3rd no., rm, and last no., layer. Thus XID.2.0.0 is equivalent to Sec XID, Cut 2, Rm, none cited, and Layer, none cited.

\section{P.2076. XID.2.0.1-2}

$4160 \pm 60$

$* 2910 \pm 60 \mathrm{BC}$

Sample 89, charcoal (Pistacea) in loose soil above Rms XXVII, XXVIII and XXII. Comments: $\mathrm{NaOH}$ pretreatment. (MT): dates to Period II, Phase 7.

P-2076-A. XID.2.0.1-2

$4080 \pm 60$

Portion of P-2076, above. Comment: NaOH pretreatment.

\section{P-2086. XIG/XIH.XX.0}

$4080 \pm 60$

Sample 94, charcoal id as Tamarix in reddish soil beneath staircase of E wall. Comment (MT): will date foundation of 'House of Stairs'. Dates to Period II, Phase 7.

\section{P-2085. RRT.9.CLXXXII.8}

$4270 \pm 60$

Charcoal (probably Tamarix), in reddish soil from floor of rm. Comment (MT): earliest layer with pottery of SS II. Dates to Period II, Phase 7.

\section{P-2084. XIM/XIL.7.CCI.0}

$4110 \pm 60$

Sample 17, charcoal (Tamarix) in loose earth as filling above main floor. Comments: NaOH pretreatment. (MT): dates to Period II, Phase 6.

\section{P-2083. XIM/XIL.6.CCI.0}

$$
4040 \pm 60
$$

Sample 15, charcoal (Tamarix) in loose earth as filling above main floor. Comment (MT): dates to Period II, Phase 6.

\section{P.2082. RSP.0.0.7}

$$
4020 \pm 70
$$
Comment (MT): dates to Period II, Phase 6. 
P-2081-B. RSP.0.0.7

$4150 \pm 70$

$* 2910-2880 \pm 70 \mathrm{BC}$

Sample 18a, charcoal (Tamarix). Stratigraphically identical to P-2082. Comment: $\mathrm{NaOH}$ pretreatment.

\section{P-2081-A. RSP.0.0.7}

Portion of P-2081-B, above.

\section{P-2079. RYL.10-11.CIVI.0}

Sample 91, charcoal (Tamarix) tral pit of rm. Comments: $\mathrm{NaOH}$ pretreatment. (MT): should determine date of bldg phase preceding that of Period IV 'Burnt Building'. Dates to Period II, Phase 5.

\section{P-2078. XIA.3.0.2}

$4180 \pm 70$ $* 2920 \pm 70 \mathrm{BC}$

Sample 90b, charcoal (Tamarix) at top of filling above, and immediately S of 'House of Foundations'. Comment (MT): dates to Period II, Phase 5 .

\section{P-2077. XIA.3.0.2}

$3950 \pm 60$ $* 2560 \pm 60$ вС above.

Sample 90a, charcoal (Tamarix) stratigraphically identical to P-2078,

\section{P-2075. RSP.0.CXXVIII.4}

$3950 \pm 60$ $* 2560 \pm 60 \mathrm{BC}$

Sample 92, charcoal (Populus) in destruction layer above floor, found near skeleton of boy. Comments: $\mathrm{NaOH}$ pretreatment. (MT): should date destruction of bldg. Dates to Period IV, Phase 2.

\section{P-2068. 0.0.CXXXVIII.4}

$$
4220 \pm 60
$$

$* 2950-2930 \pm 60 \mathrm{BC}$

Sample 71a, charcoal (?) (Tamarix) in clayish soil from fireplace, beside burnt skeleton. Comments: $\mathrm{NaOH}$ pretreatment. (MT): dates to period IV, Phase 1.

\section{P-2069. 0.0.CXXXVIII.4}

$3930 \pm 60$

Sample 71b (Populus). Stratigraphically identical to P-2068, above. Comment: $\mathrm{NaOH}$ pretreatment.

\section{P-2070. RRT.0.0.3}

$4070 \pm 60$ earth. Comments: $\mathrm{NaOH}$ pretreatment. (MT): dates to Period IV, Phase 1. 


\section{P.2073. 0.0.CXXVI.4}

$3840 \pm 60$

Sample 87a, charcoal (Populus), in destruction layer of brownish earth representing remains of fallen roof beams. Comments: $\mathrm{NaOH}$ pretreatment. (MT): dates to Period IV, Phase 1.

\section{P.2072. RWE.0.0.2}

$3750 \pm 60$ Comment (MT): dates to Period IV, Phase 0.

\section{P.2071. RWE.0.0.2}

$* 2180 \pm 60 \mathrm{BC}$ above. Comment (MT): dates to Period IV, Phase 0.

\section{Tepe Sharafabad series}

Tepe Sharafabad is small site in $\mathbf{N}$ central sector of Susiana plain $10 \mathrm{~km}$ S of Dezful, Khusistan, SW Iran $\left(32^{\circ} 7^{\prime} \mathrm{N}, 48^{\circ} 22^{\prime} \mathrm{E}\right)$. It contains important deposits dating to Sukkulmahhu and Transitional phases of Elamite period (ca 1900 to $1300 \mathrm{BC}$ ), as well as earlier material indicating relatively continuous occupation ca 5500 to 2800 вс. Subm 1974 by H T Wright, Mus Anthropol, Univ Michigan, Ann Arbor (Schacht, 1975).

\section{P-2209. Sample A}

$4260 \pm 330$

Charred wood from Excavation Unit 305 N, 300 E, Lot 22, Layer 6, a brown silt with charcoal and ash directly on floor. Assoc with ceramics of ca 1400 вс (Elizabeth Carter, pers commun). Seal of approx same date in trash layers immediately overlying brick collapse of this bldg, and tablet fragment of approx same date in fill of overlying small structure (Vallat \& Cameron, pers commun). Coll 1971 by Nancy Talbot. Comments: sample counted in small counter. (HTW): expected date close to TUNC-34, $3170 \pm 130$, and $-35,3200 \pm 140$ (R, 1973, v 15, p 595).

\section{P-2210. Samples B, C, E}

$5140 \pm 60$

Combined sample of charred wood from 340E, large, rapidly filled pit. Sample B, Lot 14, Layers 22, 25, brown silt with ash, mud brick fragments, and charcoal, in lower layers of pit (feature 3), ca 2.6m depth. Sample C, Lots 43 and 44, Layers 17-18, light brown silt with ash, mud brick fragments and charcoal in middle layers of pit, ca $2.2 \mathrm{~m}$ depth. Sample E, Lo 12, Layer 14-22, brown silt, charcoal and mud brick fragments, ash and sherds from pit, ca 2.1 to $3 \mathrm{~m}$ depth. Coll 1971 by Nancy Talbot and Richard Redding. Ceramics from pit represent very end of Middle Uruk period (for ceramic terminology, see Johnson, 1973, p 54-58). Samples combined due to small size. Comment (HTW): expected date close to TUNC-32, $4832 \pm 55$, and $-33,4331 \pm 50$ (R, 1973, v 15, p 595). 


\section{P-2281. Sample D}

$2770 \pm 270$

Sample D, charred wood from Excavation Unit 310N 295E, Lot 9, Layer 9, brown silt and charcoal layer on top of irregular floor at courtyard walls, ca $1.3 \mathrm{~m}$ depth. Assoc with ceramics of ca 1400 BC (Elizabeth Carter, pers commun). Coll 1971 by William Laubernds. Comments: sample counted in small counter. (HTW): expected date close to TUNC$34,3172 \pm 125$, and $-35,3200 \pm 138(\mathrm{R}, 1973$, v 15, p 595).

\section{Iraq}

\section{Abu Salabikh series}

Tell Abu Salabikh is a large mound, last occupied in Early Dynastic III period, ca $20 \mathrm{~km} \mathrm{NW}$ of Nippur, Iraq $\left(31^{\circ} 00^{\prime} \mathrm{N}, 42^{\circ} 30^{\prime} \mathrm{E}\right)$, on ancient course of Euphrates. Samples coll 1965 by Donald Hansen and subm by Robert Biggs, Oriental Inst, Chicago (Biggs, 1966).

\section{P-2050. Area E, Level I B}

$4850 \pm 50$

Field Sample l, charcoal from Area E, Level I $\mathrm{B}$, fill above Floor 3 . Sample from level of earliest stratified cuneiform inscriptions. Comments: $\mathrm{NaOH}$ pretreatment. (RB): expected date should be mid-3rd millennium BC, early part of Early Dynastic IIIa. Sample tested negative for bitumen.

\section{P-2051. Area E, Level I}

$$
4100 \pm 60
$$

Field Sample 2, charcoal from Area E, Level I. Comments: $\mathrm{NaOH}$ pretreatment. (RB): presumably burned at time of destruction of bldg.

\section{P-2052. Area E 31, Level I}

$4330 \pm 60$

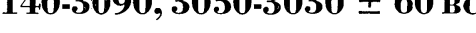
$\mathrm{NaOH}$ pretreatment.

\section{P-2053. Area E 39, Level I B}

$4390 \pm 60$

Field Sample 4, charcoal from Area E 39, Level I B, fill above Floor 3, at $\mathrm{E}$ wall. Comment: $\mathrm{NaOH}$ pretreatment.

\section{P-1117. Tell al Rimah}

$3480 \pm 60$

Ash from Tell al Rimah, $12.8 \mathrm{~km} \mathrm{~S}$ of Tell 'Afar in Sinjar region of NW Iraq $\left(46^{\circ} 26^{\prime} \mathrm{N}, 36^{\circ} 16^{\prime} \mathrm{E}\right)$. From 1 of 2 ash layers in Level II overlying dado of Site A shrine rm within platform temple on center mound of complex. Coll 1965 by J Reade, subm 1966 by David Crownover, Univ Mus, Univ Penna, Phila. Comment: NaOH pretreatment. For another date see P-844, $3291 \pm 57$ (R, 1965, v 7, p 190). 


\section{Israel}

\section{Ai (et Tell) series}

Ai (et Tell), near village of Deir Dibwan, 10km NNE of Jerusalem, Israel, $\left(31^{\circ} 55^{\prime} \mathrm{N}, 35^{\circ} 16^{\prime} \mathrm{W}\right)$, contains stratified remains of Early Bronze age (ca 3100 to $2200 \mathrm{BC}$ ) and Iron age remnants. Artifactual correlations at site exist linking EB I-EB III with Thinite to Early Old Kingdom Egypt. Samples subm 1975 by J A Callaway, Southern Baptist Theol Seminary, Louisville, Kentucky, and James Weinstein, Univ Mus, Univ Penna (Callaway, 1972; Callaway \& Wagner, 1974).

General Comment: in sample titles, letter after title denotes site, nos. designate area, sub-area, and layer, eg, G VI 500.6 = Site G, Area VI, Sub-area 500, Layer 6).

\section{P-2298. G VI 500.6}

$4170 \pm 70$

$* 2910 \pm 70 \mathrm{BC}$

Charred wood from destruction layer of EB IIIB (Phase VIII) house. Coll 1966 by $\mathrm{G} \mathrm{H}$ Livingston. Comments: $\mathrm{NaOH}$ pretreatment (JAC): sample should indicate date ca $2450 \mathrm{BC}$, at beginning of last half of EB IIIB. For another date from same provenance see $\mathrm{Tx}-1033,4400 \pm 80(\mathrm{R}$, 1972, v 14, p 483).

\section{P-2299. C I 1.28b}

$4200 \pm 70$

Charred lentils (preliminary field id by Kermit Schoonover, Perkins School Theol, Dallas, Texas) from destruction layer of house used during EB IIB, Phase V. Coll 1964 by Kermit Schoonover. Comments: NaOH pretreatment. (JAC): sample should indicate date for termination of Urban B, or EB IIB, at Ai, assigned to ca 2720 BC (Callaway, 1972, p 199201). For another date from same provenance, see Tx-1030, $4700 \pm 50$ (R, 1972, v 14, p 483).

\section{P-2300. C I 1.31}

$4250 \pm 60$
$* 2970 \pm 60$ BC

Charred lentils (see P-2299, above) from destruction layer in house next to Wall C used during EB IC, Phase III. Coll 1964 by Kermit Schoonover. Comments: $\mathrm{NaOH}$ pretreatment. (JAC): for other dates from same provenance see $\mathrm{Tx}-1035,4810 \pm 90(\mathrm{R}, 1972, \mathrm{v} 14, \mathrm{p} 483)$, and -2371 , $4310 \pm 130$ (unpub).

\section{P-2301. C IX 800.10}

$$
\begin{array}{r}
4270 \pm 70 \\
* 2990-2970 \pm 70 \text { BC } \\
\delta^{13} C_{w}=+1.82 \%
\end{array}
$$

Charred lentils (see P-2299, above) from destruction layer of Urban B house. Same location in layer succeeding Urban C phase in which samples P-2299 and -2300 belong. Coll 1966 by Kermit Schoonover. Comment (JAC): should indicate date for termination of Urban B, or EB IIB, at $\mathrm{Ai}$, assigned to ca 2720 BC (Callaway, 1972, p 199-201). For other dates from same provenance see GaK-2380, $4160 \pm 120(\mathrm{R}, 1973, \mathrm{v} 15, \mathrm{p} 66)$ and Tx-1031, $4730 \pm 90(\mathrm{R}, 1972, \mathrm{v}$ 14, p 483). 


\section{P-2302. D IV 300.5}

$4320 \pm 70$

Charred wood (Quercus calliprinos) id by Cecil Warren, Ashmolean Mus, Oxford, from Urban C temple-palace complex destruction layer, used during EB IC. Sample contemporary with P-2303 and -2304 (cf). Coll 1964 by J A Callaway. Comments: $\mathrm{NaOH}$ pretreatment. (JAG): should indicate date for beginning of Urban $\mathrm{C}$ at $\mathrm{Ai}$, or beginning of EB IC, Phase III. For other dates from same provenance, see GaK-2379, $4980 \pm 120 ;$ GaK-2381, $5000 \pm 120$ (R, 1973, v 15, p 66); Tx-1032, 4940 $\pm 90(\mathrm{R}, 1972, \mathrm{v} 14, \mathrm{p} 483)$ and $\mathrm{Tx}-2372,4380 \pm 80$ (unpub).

\section{P-2303. L I 1.8}

$4550 \pm 60$

Charred wood, presumably evergreen oak as P-2302 (above), from destruction layer of Urban C Tower C, and contemporary with P-2302 and $-2304(c f)$. Coll 1972 by J A Callaway. Comments: NaOH pretreatment. (JAC): same as for P-2302.

\section{P.2304. L I 2.2}

$4360 \pm 60$

Charred wood, presumably evergreen oak as P-2302, from destruction layer of Urban C Tower C, and contemporary with P-2302 and -2303. Coll 1972 by J A Callaway. Comment (JAC): same as for P-2302, above.

\section{Arad series}

Arad, S Israel (31 $\left.17^{\prime} \mathrm{N}, 35^{\circ} 07^{\prime} \mathrm{E}\right)$, site of important Early Bronze age city, and later acropolis town of Iron age. The 4 EB strata (IV, oldest, to I) correspond to late Gerzean-Second Dynasty periods in Egypt (Callaway \& Weinstein, ms in preparation). Samples subm 1970, 1972-1975 by Ruth Amiran, Israel Mus, Jerusalem (Amiran, 1965; 1969; 1970). All samples from Arad Strata III or II, which probably coincide with midlate 1st Dynasty. Previous date for Loc 1240, EB II city, GrN-4704, 4335 \pm 65 (R, 1967, v 9, p 139).

General Comment: grain id by Maria Hopf, Mainz, W Germany.

P-1742. Floor of Rm 2326,

Stratum II, Area K $* \mathbf{2 8 0 0 - 2 7 6 0 , 2 7 2 0 , 2 6 9 0 \pm 5 0 ~ B C}$

Charred barley, no. 5541/91, from floor of Rm 2326, Stratum II, Area K. Coll 1965 by R Brown. Comment: $\mathrm{NaOH}$ pretreatment.

\section{P-2055. Loc 4155-4158, Stratum II}

$4910 \pm 60$

Charred wheat from Loc 4155-4158, Stratum II. Coll 1972 by Ruth Amiran. Comment: $\mathrm{NaOH}$ pretreatment. 
P-2109. Loc 4155-4158, Stratum

$4070 \pm 50$

II, No. 8986

$* 2800,2740-2710,2690 \pm 50$ BC

$\delta^{18} C_{w}=+2.23 \%$

Charred wheat from Loc 4155-4158, Stratum II. Some Loc and collector as P-2055, above. Coll 1972, subm 1974. Comment (RA): date agrees with chronology beginning First Dynasty at 2970 BC.

$4510 \pm 60$

P-2054. Loc 4058-4071, Stratum II

*3340-3230 $\pm 60 \mathrm{BC}$

$\delta^{13} C_{w}=+0.88 \%$

Charred barley from Loc 4058-4071, Stratum II. Coll 1971 by Ruth Amiran. Comment: $\mathrm{NaOH}$ pretreatment.

P-2054-A. Loc 4058-4071, Stratum II

$4230 \pm 60$ $* 2960-2930 \pm 60 \mathrm{BC}$ $\delta^{13} C_{w}=+4.07 \%$

Charred barley from Loc 4058-4071, Stratum II. Sample is another portion of P-2054, see above. Comment: $\mathrm{NaOH}$ pretreatment.

P-2110. Loc 4151, Stratum II, No. 8968

$4310 \pm 60$

$3110-3070,3040-3010 \pm 60 \mathrm{BC}$ $\delta^{13} C_{v}=+3.15 \%$ Amiran

Charred barley from Loc 4151, Stratum II. Coll 1973 by Ruth

P-2415. Loc 4610, Stratum III, X-1394/91

$4210 \pm 60$ $* \mathbf{2 9 4 0 - 2 9 2 0} \pm 60 \mathrm{BC}$

Carbonized wood (id as Pistacea atlantica) from Loc 4610, Stratum III. Coll 1975 by Ruth Amiran. Comment: NaOH pretreatment.

5. Jordan

\section{P-2207. Tell Siran}

$2350 \pm 50$

$* 460-440 \pm 50 \mathrm{BC}$

Uncarbonized grain, contents of sealed Ammonite bronze container, consisting mainly of Triticum dicoccum, emmer wheat, Triticum aestivum, bread wheat, and Hordeum vulgare, hulled six-row barley, id by Hans Helbaek, Natl Mus, Copenhagen (Helbaek, 1974, p 167-168). Inscribed container found in unstratified deposit in one of a complex of subterranean chambers at Tell Siran, NW of Amman, Univ Jordan campus $\left(31^{\circ} 57^{\prime} \mathrm{N}, 35^{\circ} 56^{\prime} \mathrm{E}\right)$. Container inscription dated to ca $600 \mathrm{BC}$ by Frank Cross, Am Schools Oriental Research, Cambridge, Massachusetts. Coll 1972 and subm 1973 by H O Thompson, Am Center Oriental Research, Amman (Thompson, 1973, p 5-13). Comment (HOT): radiocarbon analysis should determine whether grain is contemporary with container.

6. Syria

\section{Tell es Sweyhat series}

Tell es Sweyhat is substantial settlement mound ca $120 \mathrm{~km} \mathrm{NE}$ of

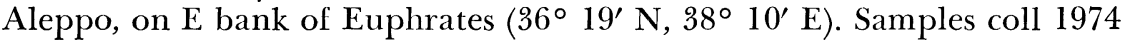


and subm 1975 by John Dayton and Tom Holland, Inst Archaeol, London. Both samples from same destruction layer, Square IV 0 p 1.4, ca $120 \mathrm{~cm}$ depth.

General Comment (JD): radiocarbon analysis should determine whether stratigraphy dates to time of Sargon, ca 2400 BC, time of Hammurabi, ca $1800 \mathrm{BC}$, or to Neo-Assyrian period, ca $800 \mathrm{BC}$.

\section{P-2324. Carbonized grain}

$3640 \pm 70$

$* 2140-2120 \pm 70 \mathrm{BC}$

Unid carbonized grain sample from jar beneath roof beam remains. Comment: $\mathrm{NaOH}$ pretreatment.

\section{P-2338. Charcoal}

$3730 \pm 70$ $* 2180 \pm 70 \mathrm{BC}$

Charcoal sample from ca $8 \mathrm{~cm}$ carbonized roof beam of poplar type, overlying P-2324, above.

\section{Turkey}

\section{P-1279. Gordion, City Mound}

$2630 \pm 50$

Gordion, on Sangarius R, ca $110 \mathrm{~km}$ SW of Ankara, Turkey $\left(39^{\circ} 45^{\prime}\right.$ $\left.\mathrm{N}, 31^{\circ} 55^{\prime} \mathrm{E}\right)$, is site of a Phrygian kingdom, destroyed during Cimmerian invasion of early 7 th century BC. City Mound contains strata dating from Chalcolithic to Galatian periods. Sample of charred grain (wheat, millet?) from burnt Phrygian house, City Mound, clay cut. Coll 1955 and subm by M J Mellink, Bryn Mawr College, Bryn Mawr, Pennsylvania. For other dates see R, 1959, v 1, p 46-47; R, 1962, v 4, p 146-149; R, 1965, v 7, p 194; R, 1966, v 8, p 352. Comment: NaOH pretreatment.

\section{P-2323. Ergani mine}

$130 \pm 80$

Carbonized wood from 30 to $45 \mathrm{~m}$ below surface in old copper mine opening, now caved in, at Ergani copper mine, $1 \mathrm{~km} \mathrm{~S}$ of Maden village, Diyabakir prov, Central Anatolia, Turkey $\left(38^{\circ} 23^{\prime} \mathrm{N}, 39^{\circ} 40^{\prime} \mathrm{E}\right)$. Coll 1962 by Sahap Aybat, Ergani Bakir Ismelleri (Ergani Copper Operations), Etibank, Maden, Turkey. Subm 1975 by C A Wendel, and P S de Jesus, Inst Archaeol, London Univ. Comment (PSdeJ): date is satisfactory; supports hypothesis that prehistoric mines have been erased by modern exploitation or that they have already caved in.

\section{P-2285. Ergani Maden (Ergani mine)}

$>\mathbf{3 7 , 5 9 0}$

Samples (wood) of mine timbers from suspected ancient copper source at Ergani copper mine, Diyabakir prov, Central Anatolia, Turkey (38 $\left.23^{\prime} \mathrm{N}, 39^{\circ} 40^{\prime} \mathrm{E}\right)$. Coll 1968 by Theodore Wertime and subm 1975 by Robert Maddin, Lab for Research and Study of Matter, Univ Pennsylvania (Wheeler et al, 1975, p 34, 37). Comment: age quoted represents 2 standard deviations of uncertainty in counting of sample, background, and modern calibration sample. No explanation for anomalously early date. 


\section{P-2208. Karataş-Semayük}

$4120 \pm 70$

$* 2870-2850 \pm 70$ BC

Karataş-Semayük is small Early Bronze age site $8 \mathrm{~km} \mathrm{E}$ of Elmali on upland plain of Elmali in interior of ancient Lycia, Antalya, Turkey $\left(36^{\circ}\right.$ $45^{\prime} \mathrm{N}, 30^{\circ} 00^{\prime} \mathrm{E}$ ). Mound is 3 to $4 \mathrm{~m}$ high, $100 \mathrm{~m}$ diam, lying $\mathrm{NE}$ of large necropolis. Sample from Storage Pit 14, S of house courtyard, Level II. Coll 1973 and subm 1974 by M J Mellink, Bryn Mawr Coll, Bryn Mawr, Pennsylvania (Mellink, 1972). For other dates see R, 1966, v 8, p 352-353. Date expected to be not far into 3rd millennium BC. Comment: $\mathrm{NaOH}$ pretreatment.

\section{P.1620. Mount Ararat}

$$
\begin{array}{r}
1340 \pm 50 \\
\text { * }_{\text {AD } 650} \pm \mathbf{5 0}
\end{array}
$$

Wood sample from tree belonging to white oak group (Quercus $s p$ ), id by B F Kukachka, Forest Prod Lab, US Dept Agric, Madison, Wisconsin. Found at $+4000 \mathrm{~m}$ under $30 \mathrm{~cm}$ ice and moraine, exposed by thawing $10 \mathrm{~m}$ ice pack, on SW face of Mount Ararat, Turkey $\left(39^{\circ} 20^{\prime} \mathrm{N}, 44^{\circ} 00^{\prime}\right.$ E). Sample coll 1969 and subm by SEARCH Foundation Inc, Washington, DC. For previous date from same site see NPL-61, $1190 \pm 90$ (R, 1965, v 7, p 161; Navarra, 1956).

\section{SW Asia}

\section{Afghanistan}

\section{Deh Morasi Ghundai series}

Deh Morasi Ghundai is Chalcolithic site in S-central Afghanistan $\left(31^{\circ} 35^{\prime} \mathrm{N}, 65^{\circ} 30^{\prime} \mathrm{E}\right)$. Samples coll 1951 and subm 1960 by Louis Dupree (1963). For other date from this site see P-1493, $4414 \pm 53$ (R, 1970, v 12, p 586).

General Comment: all samples except P-2291 counted in small counter.

\section{P-2288. 100 to $120 \mathrm{~cm}$}

$3780 \pm 240$

Charcoal from 100 to $120 \mathrm{~cm}$ depth.

\section{P-2289. 220 to $240 \mathrm{~cm}$}

$4440 \pm 260$

Fire-burned earth and some charred wood from 220 to $240 \mathrm{~cm}$ depth.

\section{P-2290. 240 to $260 \mathrm{~cm}$}

$4090 \pm 220$

(1) $260 \mathrm{~cm}$ depth.

$4500 \pm 70$

P-2291. 260 to $280 \mathrm{~cm} \quad * 3330,3300-3280,3250-3220 \pm 80 \mathrm{BC}$

Fire-burned earth and some charred wood from 260 to $280 \mathrm{~cm}$ depth.

$5680 \pm 300$

P-2292. 290 to $300 \mathrm{~cm}$

$* 4540 \pm 310 \mathrm{BC}$

Fire-burned earth and some charred wood from 290 to $300 \mathrm{~cm}$ depth. 


\section{Shamshir Ghar series}

Shamshir Ghar is historic period cave site ca $100 \mathrm{~m}$ above Arghanab $\mathrm{R}$, near village of Badwan, Kandahar prov, Afghanistan $\left(31^{\circ} 35^{\prime} \mathrm{N}, 65^{\circ}\right.$ $30^{\prime}$ E). Samples coll 1950 and subm 1960 by Louis Dupree (1958).

General Comment: samples counted in small counter.

\section{P-2286. 40 to $50 \mathrm{~cm}$, Trench 2}

$1750 \pm 220$

*AD $210 \pm 230$

Fire-burned earth and some charred wood from Trench 2, 40 to $50 \mathrm{~cm}$ depth. Comment: on typologic grounds, date expected to be AD 100 to 300 .

\section{P-2287. 50 to $60 \mathrm{~cm}$, Trench 2}

$2780 \pm 250$

$* 1010 \pm 260$ в

Fire-burned earth and some charred wood from Trench 2, 50 to $60 \mathrm{~cm}$ depth. Comment: on topologic grounds date expected to be AD 100 to 300 .

\section{Pakistan}

\section{Aligrama series}

Aligrama is in Swat Valley, Pakistan (34 $\left.37^{\prime} \mathrm{N}, 72^{\circ} 22^{\prime} \mathrm{E}\right)$. Samples coll 1973 and subm 1974 by Giorgio Stacul, Inst Storio Antica, Univ Trieste, Italy (Stacul, 1969; 1970).

\section{P-2150. Layer 10}

$3090 \pm 40$

Carbon from Layer 10,3.60 to $3.80 \mathrm{~m}$ depth, assoc with pottery re lated to early Vth period. For other dates for Period V in Swat Valley see BM-195, $2980 \pm 150$, BM-196, $2850 \pm 150$ (R, 1969, v 11, p 292) and $\mathrm{R}-476,3150 \pm 150(\mathrm{R}, 1970, \mathrm{v} 12, \mathrm{p} 610)$.

\section{P-2151. Layer 13}

$3010 \pm 60$ related to IVth period.

\section{P-2151. Layer 13}

$3350 \pm 40$

Carbon from hearth in Layer $13,5.75 \mathrm{~m}$ depth, assoc with potery related to IVth period.

\section{Allahadino series}

Allahdino is Harappan-period site near Karachi, Pakistan $\left(24^{\circ} 52^{\prime}\right.$ N, $67^{\circ} 20^{\prime}$ E). Samples coll 1974 by W A Fairservis, Jr; subm by Gregory Possehl, Univ Mus, Univ Pennsylvania.

General Comment (WAF): samples from high on site. Only P-2296 could qualify as assoc with main bldg period; P-2237 and -2295 from last phase of occupation. 
P-2237. Sq E 5

*2410-2340 $\pm 70 \mathrm{BC}$

Charcoal from small burned area in $\mathrm{Sq} 5 \mathrm{E}, 60 \mathrm{~cm}$ from $\mathrm{N}$ balk, $60 \mathrm{~cm}$ depth. Date expected to be $2000 \pm 200$ BC.

\section{P-2295-A. Building Level I, 40cm depth}

$3760 \pm 70$

Charcoal from Bldg Level I, 40cm depth. Date expected to be 1900 \pm 200 вс. Comment: $\mathrm{NaOH}$ pretreatment.

\section{P.2296. Building Level I, 60cm depth $\quad * 2550 \pm \mathbf{5 0} \mathbf{~ B C}$}

Charcoal from Bldg Level I, 60cm depth. Date expected to be 1900 \pm 200 BC.

\section{P-2294. Periano Ghundai}

$870 \pm 50$

*AD $1090 \pm 50$

Charcoal from bottom of Stein's Trench E, at Periano Chundai, a multi-period mound site in Zhob Valley, N Baluchistan, Pakistan $\left(31^{\circ}\right.$ $\left.35^{\prime} \mathrm{N}, 65^{\circ} 30^{\prime} \mathrm{E}\right)$. Original excavation produced 2 distinct stratigraphic phases with later phase revealed in Trench E (Stein, 1929; Fairservis, 1959, p 329-330). Coll 1950 and subm 1960 by Louis Dupree. Comment: $\mathrm{NaOH}$ pretreatment.

\section{Rana Ghundai series}

Rana Ghundai is 5 th to 3 rd millennium BC site in Loralai Valley of

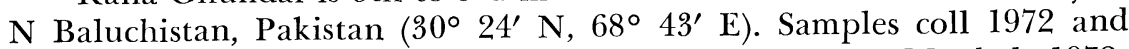
subm by M R Mughal, Dept Archaeol, Govt Pakistan (Mughal, 1972; 1974; Fairservis, 1959).

\section{P.2148. Sample 2}

$$
\begin{array}{r}
5580 \pm 60 \\
* 4470 \pm 60 \text { BC }
\end{array}
$$

Charcoal, earth and ash from occupation level in already exposed sec on W edge of site. Sample from $3 \mathrm{~m}$ below arbitrary datum, in level which may belong to either Rana Ghundai I Period or to occupation preceding Period I.

\section{P-2149. Sample 3}

$4600 \pm 60$

Burned material and ash from occupation deposit (ca $22 \mathrm{~cm}$ thick, max) from already exposed sec containing charcoal and carbonized seeds, belonging to Rana Ghundai IIIA period. For comparably dated material from Damb Sadaat II-III, see P-522, $4378 \pm 196 ;$ P-523, $4029 \pm 74$ (R, 1963, v 5, p 94) and from Kot Diji, see P-195, $3925 \pm 134 ;$ P-180, $4083 \pm$ 137; P-179, $4161 \pm 151$, and P-196, $4421 \pm 141(\mathrm{R}, 1959, \mathrm{v} 1, \mathrm{p} 51)$.

\section{Ethiopia}

$$
\text { D. Africa }
$$

\section{Aksum series}

Aksum, capital of Aksumite Kingdom of 1st millennium AD is on W side of $\mathrm{N}$ Ethiopian plateau $\left(14^{\circ} 8^{\prime} \mathrm{N}\right.$, $\left.38^{\circ} 48^{\prime} \mathrm{E}\right)$. Samples subm by Neville Chittick, British Inst in E Africa, Nairobi, Kenya (Chittick, 1974). 
P-2310. XXII A (5a)

$1960 \pm 40$

Sample XXII A (5a), charcoal from pit underlying fill of 2nd extension to earliest structure (Platform A) beneath main group of stelae, ca $2.6 \mathrm{~m}$ depth. Coll 1974 by John Manley.

P-2311. XXII H (5)

$1820 \pm 50$

*AD $150 \pm 50$

Sample XXII H (5), charcoal on steps leading to extended platform beneath main group of stelae, ca $2.4 \mathrm{~m}$ depth. Coll 1974 by John Manley.

P-2312-A. XXII H (5d)

$1610 \pm 40$

Sample XXII H (5d), charcoal from (5eposis accumulated platforms, ca $2.4 \mathrm{~m}$ depth. pretreatment. $(\mathrm{NC})$ : expected date to be slightly later than P-2311, above.

\section{P-2313. Sample XII FW (6a)}

$1690 \pm 180$

Charcoal from bottom of pit, ca $6 \mathrm{~m}$ depth, cut throug "platorm", deposits probably in Late Aksumite times. Coll 1974 by John Manley. Comments: sample counted in small counter. (NC): date expected to be later than P-2310 and -2312-A, above, which would indicate robber activities in Late Aksumite times, but sample may possibly predate pit.

\section{P.2314. Sample DA (15)}

$1680 \pm 80$

*AD $280 \pm 80$

Charcoal from outer part of left chamber of "Tomb of Brick Arches," against steps, at 8m depth. Coll 1974 by S Munro-Hay. Comments: $\mathrm{NaOH}$ pretreatment. (NC): sample should date furnishing of tomb, though it is possible that material was left by robbers in antiquity.

\section{P-2315. Sample GT II (11)}

$1720 \pm 220$

*AD 230-250 \pm 220

Charcoal from tomb chamber in Gudit stele field. Coll 1974 by W Ball. Comments: $\mathrm{NaOH}$ pretreatment. Sample counted in small counter. $(\mathrm{NC})$ : on basis of grave goods, $3 \mathrm{rd}$ to 4 th century $\mathrm{AD}$ date expected.

\section{P-2316. Sample IW II (5)}

$1550 \pm 50$

*AD $440 \pm 50$

Charcoal from lowest fill of burned Bldg IW, ca $1.5 \mathrm{~m}$ depth, assoc with stone bowls. Coll 1974 by W Ball. Comments: $\mathrm{NaOH}$ pretreatment. (NC): Late Aksumite date expected, which should indicate terminus post quem for destruction of bldg.

\section{P-2317. Sample IW IA (3)}

$1890 \pm 50$

$*_{A D} 90 \pm 50$

IW IA (3), charcoal in collapse of burned bldg IW, ca $1 \mathrm{~m}$ depth. Coll 1974 by W Ball. Comments: $\mathrm{NaOH}$ pretreatment. (NC): sample is probably part of beam from structure of house. Date expected to be older than P-2316, above. 
P-2238. Gobedra Rockshelter

$10,110 \pm 140$

Gobedra rockshelter is 1 of series of rockshelters at $\mathrm{W}$ end of Gobedra ridge, $6 \mathrm{~km} \mathrm{~W}$ of Aksum, Tigre, N Ethiopia $\left(14^{\circ} 10^{\prime} \mathrm{N}, 38^{\circ}\right.$ 45' E). Coll and subm 1974 by D W Phillipson, British Inst in E Africa, Nairobi, Kenya. Charcoal from Grid-Sq S, Level 7/8 interface, 65 to $75 \mathrm{~cm}$ depth. Assoc with earliest phase of microlithic "Late Stone Age" industry, overlying industry based on large blades. Later phases of microlithic industry assoc with pottery of previously unknown type (Chittick, 1974, p 194). Comment: date calculated with 5730 half-life, but not corrected $=8460 \pm 140 \mathrm{BC}$.

\section{USA}

\section{E. N America}

\section{P-1809. Nuk, Alaska}

Charcoal from hearth in single habitation level of House 285, Nuk, $29 \mathrm{~km} \mathrm{E}$ of Nome, Alaska $\left(64^{\circ} 30^{\prime} \mathrm{N}, 166^{\circ} 00^{\prime} \mathrm{W}\right)$. Coll 1970 by $\mathrm{J} \mathrm{R}$ Bockstoce, subm by F G Rainey, Univ Mus, Univ Pennsylvania. Comparable date for same site, I-5379, $1970 \pm 100$ (FGR, personal commun). Other date for same site P-1633, $2284 \pm 56$ (R, 1971, v 13, p 372). Comment: $\mathrm{NaOH}$ pretreatment. Sample was processed at Univ Pennsylvania Radiocarbon Lab, but was too small for our counters, therefore counted by Isotopes.

\section{P-2440. Fort Hill, Pennsylvania}

$2430 \pm 200$ $\left.79^{\circ} 17^{\prime} \mathrm{W}\right)$. Sample from interface of tan-ferrous clay and dense-dry siltstone, at $0.4 \mathrm{~m}$ depth. Coll and subm 1976 by Jeffrey Kenyon, Univ Mus, Univ Pennsylvania. Comment: sample counted in small counter.

\section{F. Caribbean}

\section{P.1402. Cap Haïtien Wreck}

$230 \pm 40$

AD $1640 \pm 40$

Wood from rudder of wreck in area of Cap Haïtien, Haiti $\left(19^{\circ} 47^{\prime}\right.$ $\left.\mathrm{N}, 72^{\circ} 17^{\prime} \mathrm{W}\right)$. Remains located on coral reef at location consistent with presumed site of wreck of Santa Maria, flagship of Christopher Columbus, which sank Dec 1492. Coll and subm 1967 by Fred Dickson, Dimeco Inc, Ocean City, New Jersey. Comment: sample taken from outermost growth rings of rudder heavily contaminated with shell casings of marine shipworms. MASCA thermoluminescence date series obtained from pottery sample assoc with wreck produced average value equivalent to AD 1475 $\pm 100(\mathrm{P}-\mathrm{T}-126)$.

\section{Costa Rica}

\section{G. Central America}

\section{Chahuite Escondido series}

Chahuite Escondido is shell midden site in Guanacaste prov on $\mathrm{E}$ bank of Rio Murcielago, $1 \mathrm{~km} \mathrm{~S}$ of Juantillo Bay on N shore of Santa 
Elena Peninsula, Costa Rica $\left(10^{\circ} 55^{\prime} \mathrm{N}, 85^{\circ} 40^{\prime} \mathrm{W}\right)$. B1 cut 1 (B1/1) was in deepest part of midden. Coll 1960 by M D Coe, subm 1974 by J W Sweeney, Dept Anthropol, Univ Pennsylvania (Baudez, 1967; Baudez \& Coe, 1962; Coe, 1962; Coe \& Baudez, 1961). For another date from this site see $\mathrm{Y}-816,840 \pm 70(\mathrm{R}, 1961, \mathrm{v} 3, \mathrm{p} 133)$.

P.2168. B1/1C

$1070 \pm 50$

*AD $920 \pm 50$

Charcoal, Field Cat No. B1/1C, Cut 7, level 0.60 to $0.90 \mathrm{~m}$. Comment: $\mathrm{NaOH}$ pretreatment.

P-2169. B1/1D

$870 \pm 40$

Charcoal, Field Cat No. B1/1D, Cut 1, level 0.90 to $1.20 \mathrm{~m}$. Comment: $\mathrm{NaOH}$ pretreatment.

P.2170. B1/1F

$1030 \pm 50$

Charcoal, Field Cat No. Bl/1F, Cut 1, level 1.50 to $1.80 \mathrm{~m}$. Comment: $\mathrm{NaOH}$ pretreatment.

P-2171. B1/1G

$720 \pm 50$

*AD $1240 \pm 50$

Charcoal, Field Cat No. B1/1G, Cut 1, level 1.80 to $2.10 \mathrm{~m}$. Comment: $\mathrm{NaOH}$ pretreatment.

P-2172. B1/1I

$950 \pm 40$

Charcoal, Field Cat No. B1/1I, Cut 1, level 2.40 to $2.70 \mathrm{~m}$. Comment: $\mathrm{NaOH}$ pretreatment.

P-2173. B1/1J

$880 \pm 50$

*AD $1090 \pm 50$

Charcoal, Field Cat No. B1/1J, Cut 1, level 2.70 to $3 \mathrm{~m}$. Comment: $\mathrm{NaOH}$ pretreatment.

P-2174. B1/1L

$1110 \pm 40$

Charcoal, Field Cat No. B1/1L, Cut 1, level 3.30 to $3.60 \mathrm{~m}$.

$*_{A D} 860-880 \pm 40$

P.2282. B1/1E

$1030 \pm 50$

Charcoal, Field Cat No. B1/1E, Cut 1, level 1.20 to $1.50 \mathrm{~m}$.

$$
\text { *AD } 950 \pm 50
$$

P-2283. B1/1H

$1040 \pm 50$

$*_{\text {AD }} 940 \pm 50$

Charcoal, Field Cat No. B1/1H, Cut 1, level 2.10 to $2.40 \mathrm{~m}$.

P-2284. B1/1K

$1120 \pm 40$

Charcoal, Field Cat No. Bl/1K, Cut 1, level 3 to $3.30 \mathrm{~m}$. 


\section{Matapalo series}

Matapalo (Site G 11) is an extensive village site beginning at modern Matapalo and covering a wide area to ca $1 \mathrm{~km} \mathrm{NW}$ of town, located $\mathrm{W}$ of Rio Matapalo, NW of Matapalo Plaza, Guanacaste prov, Costa Rica $\left(10^{\circ} 20^{\prime} \mathrm{N}, 85^{\circ} 50^{\prime} \mathrm{W}\right)$. Site pertains to Zoned Bichrome and Early Polychrome periods. (Baudez \& Coe, 1962; Coe, 1962; Coe \& Baudez, 1961; Lange, 1971). Coll 1960 by M D Coe and subm 1974 by J W Sweeney. For other dates from this site see Y-810, $1870 \pm 200$; Y-809, $1530 \pm 280$; and $\mathrm{Y}-811,1395 \pm 90(\mathrm{R}, 1961, \mathrm{v} 3, \mathrm{p} 132)$.

\section{P.2175. G11/1C}

$740 \pm 40$

Charcoal, Field Cat No. G11/1C, Cut 1, level 0.30 to $0.45 \mathrm{~m}$. Comment: $\mathrm{NaOH}$ pretreatment.

\section{P-2176. G11/1D}

$1040 \pm 50$

Charcoal, Field Cat No. G11/1D, Cut l, level 0.45 to $0.60 \mathrm{~m}$. Com ment: $\mathrm{NaOH}$ pretreatment.

\section{P-2177. G11/2D and G11/2E}

$1330 \pm 50$

Charcoal, Field Cat Nos. G11/2D, Cut 1 , level 0.45 to $0.60 \mathrm{~m}$ and G11/2E, Cut 1 , level 0.60 to $0.75 \mathrm{~m}$. Comment: 2 samples combined.

\section{Huerta del Aguacate series}

Huerta del Aguagate site is one of series of shell mounds within $200 \mathrm{~m}$ radius near Villareal, Guanacaste prov, on N side of Rio San Andrés ca $2 \mathrm{~km} \mathrm{E}$ of Tamarindo Bay $\left(10^{\circ} 15^{\prime} \mathrm{N}, 85^{\circ} 50^{\prime} \mathrm{W}\right)$. Presumed to be single period site pertaining to Middle Polychrome period (AD 800-1200) but there may be an earlier component (Baudez, 1967; Lange, 1971). Coll 1960 by M D Coe, subm 1974 by J W Sweeney. For another date see Y-815, $990 \pm 70$ (R, 1961, v 3, p 132-133).

P-2178. G2/1C

$810 \pm 40$

$*_{A D} 1180 \pm 40$

Charcoal, Field Cat No. G2/1C, Cut 1, level 0.30 to $0.45 \mathrm{~m}$. Comment: $\mathrm{NaOH}$ pretreatment.

P-2179. G2/1D

$930 \pm 40$

$*_{A D} 1030 \pm 40$

Charcoal, Field Cat No. G2/1D, Cut 2, level 0.45 to $0.60 \mathrm{~m}$. Comment: $\mathrm{NaOH}$ pretreatment.

P-2180. G2/2F

$760 \pm 50$

$*_{\text {AD }}$ 1200-1220 \pm 50

Charcoal, Field Cat No. G2/2F, Cut 2, level 0.75 to $0.90 \mathrm{~m}$.

P-2181. G2/2G

$1130 \pm 40$

*AD $850 \pm 40$

Charcoal, Field Cat No. G2/2G, Cut 2, level 0.90 to $1.05 \mathrm{~m}$. 


\section{Guatemala}

\section{San Jeronimo Basin series}

All 3 sites in San Jeronimo Basin, Salama Valley, Guatemala $\left(15^{\circ} 5^{\prime}\right.$ N, $90^{\circ} 12^{\prime}$ W) (Sedat \& Sharer, in press; Sharer \& Sedat, 1973; Sedat \& Sharer, 1973).

\section{El Porton (Site SV-3)}

El Porton is Late Preclassic, ca 300 BC - AD 200, ceremonial center ca $1 \mathrm{~km} \mathrm{~W}$ of town of San Jeronimo. Samples coll 1972 by D W Sedat, subm 1973 by R J Sharer, Univ Mus, Univ Pennsylvania.

\section{P-2132. EP 1-1.4/10 C.25}

$2260 \pm 60$

C. J7-2. Comments: $\mathrm{NaOH}$ pretreatment. (RJS): cache 25 may be intrusive.

\section{P-2133. EP 1-1.4/8}

$1960 \pm 40$

*AD 30-50 \pm 40

EP 1-1.4/8, charcoal from burned surface in Structure J7-2. Comment: $\mathrm{NaOH}$ pretreatment.

\section{P-2134. EP 1-1.8/10A}

$2300 \pm 50$ depth, in Structure J7-2. Comment: $\mathrm{NaOH}$ pretreatment.

\section{P-2135. EP 1-1.8/10B}

$$
* 430 \pm 50 \text { вС }
$$
$390 \mathrm{~cm}$ depth, in Structure J7-2. Comment: $\mathrm{NaOH}$ pretreatment.

P-2136. EP 2-1.3/10

$2160 \pm 60$

$$
\begin{array}{r}
2230 \pm 60 \\
* 400 \pm 60 \mathrm{BC}
\end{array}
$$

EP 2-1.3/10, charcoal and sand from hearth in Structure J7-4, 915 to $335 \mathrm{~cm}$ depth. Comment: $\mathrm{NaOH}$ pretreatment. Sample undersized, $85.33 \%$.

\section{P-2137. EP 2-1.3/12}

$2230 \pm 60$ depth. Comment: $\mathrm{NaOH}$ pretreatment.

\section{P-2138. EP 2-1.3/7 C.32E}

$2320 \pm 50$

EP 2-1.3/7 C.32E, charcoal and sand from Cache 32E, Structure J7-4. Comments: $\mathrm{NaOH}$ pretreatment. (RJS): Cache 32E may be intrusive.

\section{Las Tunas (Site SV-15)}

Samples from early Middle Preclassic, 900 to $500 \mathrm{BC}$, ceremonial platform at Las Tunas, ca $4 \mathrm{~km}$ W of San Jeronimo. Coll 1973 by D W Sedat; subm 1974 by R J Sharer. 
P-2219. LT 3-2.1/4B

$2140 \pm 70$

LT 3-2.1/4B, charcoal from midden over stairs and plaza surface. Expected date later than P-2220. Comment: $\mathrm{NaOH}$ pretreatment.

\section{P-2220. LT 3-2.1/3B}

$2180 \pm 60$

, tion. Date expected to be earliest in series. Comment: $\mathrm{NaOH}$ pretreatment.

\section{P-2221. LT 1-1.3/5}

$2020 \pm 60$

LT 1-1.3/5, charcoal from burned debris on floor. Should date use or abandonment of construction. Date expected to be latest in series. Comment: $\mathrm{NaOH}$ pretreatment.

\section{P-2222. LT 1-1.3/4}

$2300 \pm 50$

$* 430 \pm 50$ в

LT 1-1.3/4, charcoal from construction fill, 190 to $200 \mathrm{~cm}$ depth. Comment: $\mathrm{NaOH}$ pretreatment.

\section{Los Mangales (Site SV-13)}

Samples from Middle Preclassic, ca 900 to 300 BC, burial mound at Los Mangales, ca $1 \mathrm{~km}$ N of town of San Jeronimo. Coll 1972 by D W Sedat; subm 1973 by R J Sharer.

\section{P-2139. LM 5-1/11A and $B$}

$2290 \pm 50$

$* 420 \pm 50$ BC

LM 5-1/11A and B, charcoal and soil from inside oven, 160 to $200 \mathrm{~cm}$ depth. Comment: $\mathrm{NaOH}$ pretreatment.

\section{P-2140. LM 1-1/3A}

$360 \pm 40$

*AD 1460-1500 \pm 40

LM 1-1/3A, bone (organic and inorganic fractions) from Burial 6 , sealed tumulus.

Malo Is, New Hebrides

$$
\text { H. S Pacific }
$$

\section{P-2087. Batuniurunga}

$970 \pm 50$

$*_{A D} 1010 \pm 50$

Charcoal and charred bone from Batuniurunga, Malo Is $\left(15^{\circ} 45^{\prime} \mathrm{S}\right.$, $\left.167^{\circ} 10^{\prime} \mathrm{E}\right)$, Location C, NHMa-101-C 1A, Feature 1, a hearth on living floor of house on shell midden. Coll 1973 and subm by J D Hedrick, Dept Anthropol, Univ Pennsylvania. Expected date, AD 1200 (Hedrick, 1971). Comment: $\mathrm{NaOH}$ pretreatment.

\section{P-2089. Avunamatala rock shelter}

$190 \pm 30$

*AD $1650 \pm 40$

Charcoal from hearth in Avunamatala rock shelter, Malo Is, NHMa9, Test Pit A, 0 to $15 \mathrm{~cm}$, Feature 1, a hearth at $15 \mathrm{~cm}$ depth. Site is a dry rock shelter cave. Sample dates end of ceramic sequence at site. Coll 
1972 and subm by J D Hedrick. Expected date AD 1200 (Hedrick, 1971). Comment: $\mathrm{NaOH}$ pretreatment.

\section{Far East}

\section{Indonesia}

\section{Tianko Panjang Cave series}

Samples from Tianko Panjang Cave, Sungai Manau kecamatan, Sarko kabupaten, Jambi Province, Sumatra, Indonesia $\left(2^{\circ} 05^{\prime} \mathrm{S}, 101^{\circ}\right.$ $58^{\prime}$ E). Coll 1973 and subm by Bennet Bronson, Field Mus Nat Hist, Chicago (Bronson et al, 1973).

General Comment (BB): all samples except No. 15 from Stratum B, very thick and internally undifferentiated pre-pottery levels underlying sherd-containing Stratum A. Expected dates post-Pleistocene and preMetal age.

\section{P-2284. 5 and 6 combined}

Sample 5, charcoal from Trench B, Stratum B, Lot 6, 179.5 to $183 \mathrm{~cm}$ below datum. Sample 6, charcoal from Trench B, Stratum B, Lot 7, 186 to $203 \mathrm{~cm}$ below datum. Comment: date calculated with 5730 half-life, but $n o t$ corrected $=7260 \pm 130$ BC.

\section{P-2249. 7, 9, and 11 combined}

$9300 \pm 120$

Sample 7, charcoal from Trench B, Stratum B, Lot 8, 206.5 to $210 \mathrm{~cm}$ below datum. Sample 9, charcoal from Trench B, Stratum B, Lot 8, 208 to $208 \mathrm{~cm}$ below datum. Sample 11, charcoal from Trench B, Stratum B, Lot 9,215 to $217 \mathrm{~cm}$ below datum. Comment: date calculated with 5730 half-life, but not corrected $=7630 \pm 130$ BC.

\section{P-2250. 13, 14, and 15 combined}

$9950 \pm 130$

Sample 13, charcoal from Trench B, Stratum B, Lot 10, 222 to $227 \mathrm{~cm}$ below datum. Sample 14, charcoal from Trench B, Stratum B, Lot 10, 222 to $232 \mathrm{~cm}$ below datum. Sample 15, charcoal from Trench B, Stratum C, Lot 11,235 to $248 \mathrm{~cm}$ below datum. Stratum G should be older than Stratum B. Date for P-2250 expected to be older than P-2249. Comment: date calculated with 5730 half-life, but not corrected $=8300 \pm 140 \mathrm{BC}$.

\section{Ireland}

\section{J. N Europe}

\section{Dun Ailinne series}

Samples of old sod from Don Ailinne, Knockaulin Townland, Kilcullen, Co Kildare, Ireland (53 $\left.13^{\prime} \mathrm{N}, 6^{\circ} 35^{\prime} \mathrm{W}\right)$, Iron age ceremonial site overlying Neolithic remains. Coll 1975 by Bernard Wailes, subm by Kathleen Ryan, Univ Mus, Univ Pennsylvania (Wailes, 1974). For other dates from this site see R, 1973, v 15, p 399-400. For thermoluminescence date from this site, see Carpenter \& Ryan (1975). 
P-2410. Old sod under small bank

$3490 \pm 60$ at entrance

Sample 1, Grid Ref 65100 51750, Cutting 64-50, old sod layer covered by small bank at original entrance through bank and ditch enclosing site.

\section{P-2411. Old sod under main bank}

$2410 \pm 60$ $* 640-500 \pm 60 \mathrm{BC}$

Sample 2, gray soil and iron pan from old sod layer covered by bank enclosing site.

\section{Narraghmore series}

Samples from rescue excavation of quarried-out ringfort at Narraghmore, Co Kildare, Ireland $\left(53^{\circ} 03^{\prime} \mathrm{N}, 6^{\circ} 50^{\prime} \mathrm{W}\right)$. Samples from old ground level buried by construction or surrounding bank and ditch, and should pre-date occupation of site. Excavation produced no closely datable finds. Coll 1975 by Thomas Fanning; subm by Kathleen Ryan (Fanning, 1972).

\section{P-2412. Old sod below bank}

$1580 \pm 170$

*AD $400 \pm 180$

Field Sample 4, soil and charcoal from old sod layer buried by construction of bank and ditch. Comment: sample counted in small counter.

\section{P-2413. Old sod below bank}

$$
\begin{array}{r}
1945 \pm 60 \\
* \text { AD 110-130 } \pm 60
\end{array}
$$

Field Samples 8 and 9, soil and charcoal from old sod layer buried by construction of bank and ditch.

\section{Canada}

\section{GEOLOGIC SAMPLES}

\section{A. $N$ America}

\section{Beaufort Sea series}

Sediment samples from 2 cores taken in Beaufort Sea $>200 \mathrm{~km}$ from shore. Core $809\left(71^{\circ} 31^{\prime} \mathrm{N}, 138^{\circ} 11^{\prime} \mathrm{W}\right)$. Core $810\left(71^{\circ} 00^{\prime} \mathrm{N}, 138^{\circ} 15^{\prime}\right.$ W). Coll 1970 and subm 1975 by G Vilks, Atlantic Geosci Centre, Geol Survey of Canada, Bedford Inst Oceanog.

General Comment: measurements in $\mathrm{cm}$ indicate depth below sedimentwater interface.

P-2370. Core 810, 1000 to $1075 \mathrm{~cm}$

Submitter's Sample H69-050. Comment: sample given 7 counts of 1000 mins each. Age limit quoted represents 2 standard deviations of the uncertainties of sample, background and modern calibration sample.

P-2371. Core 809, 675 to $750 \mathrm{~cm}$

$30,960 \stackrel{1830}{+1490}$

Submitter's Sample H69-809. 
P-2372. Core 810, 371 to $460 \mathrm{~cm}$

Submitter's Sample H69-810.

P-2373. Core 809, 250 to $350 \mathrm{~cm}$

No sample no. given.

\section{P.2141. Griffith I.}

Sample III, collagen extracted from whale bones on raised beach, SH Griffith I., Dist of Franklin, NW Terr, Canada, 22km S of Cornwallis I. $\left(74^{\circ} 33^{\prime} \mathrm{N}, 95^{\circ} 30^{\prime} \mathrm{W}\right)$. Coll 1973 by J G Bockheim and T M Ballard; subm by J G Bockheim, Dept Geol, Univ Pennsylvania.

\section{P-2142. Intrepid Bay}

$$
\begin{array}{r}
\mathbf{8 3 5 0} \pm \mathbf{8 0} \\
\delta^{13} C_{w}=+26.39 \% o
\end{array}
$$

Sample I, unid shells from Cornwallis I., Dist Franklin, NW Terr, Canada, $0.5 \mathrm{~km} \mathrm{~W}$ of Coal Lakes and $50 \mathrm{~km} \mathrm{~N}$ of Resolute $\left(75^{\circ} 02^{\prime} \mathrm{N}\right.$, $\left.96^{\circ} 02^{\prime} \mathrm{W}\right)$. Contained in silt and clay, overlying quartzose sand and coal-bearing strata. Sediments have recently been ascribed to late Cretaceous - early Tertiary Eureka Sound formation (Thorsteinsson \& Kerr, 1967). Coll 1973 by J G Bockheim and T M Ballard, subm by J G Bockheim. Comment: date calculated with 5730 half-life but not corrected $=6650 \pm 80 \mathrm{BC}$.

\section{Iceland}

P-2367. Icelandic Highlands

$>41,900$

Sample of wood buried by volcanic debris from Icelandic Highlands, NW Iceland $\left(66^{\circ} 10^{\prime} \mathrm{N}, 23^{\circ} 22^{\prime} \mathrm{W}\right)$. Subm by Charles Price, Dept Chemistry, Univ Pennsylvania and J D Hallahan.

3. $U S A$

P.1360. La Porte, Texas

Wood encountered at depth of ca $77 \mathrm{~m}$ during excavation of water well at La Porte, Texas, plant of I E Dupont Co $\left(29^{\circ} 42^{\prime} \mathrm{N}, 95^{\circ} 02^{\prime} \mathrm{W}\right)$. Coll 1967 by H D Failing, subm 1967 by W Hageman and Froelich Rainey, Univ Mus, Univ Pennsylvania. Comment: age limit quoted represents 2 standard deviations of the uncertainties of sample, background and modern calibration sample.

\section{B. Europe}

1. Azores

P.2165. San Miguel

$4760 \pm 60$

$* 3610 \pm 60 \mathrm{BC}$

Azores charcoal No. 1 (a), carbonized wood from trees engulfed by latest pumiceous tuff in area, Agua de Pau volcano, San Miguel, Azores $\left(37^{\circ} 43^{\prime} \mathrm{N}, 25^{\circ} 28^{\prime} \mathrm{W}\right)$. Coll 1973 and subm 1974 by J M Ade-Hall, 
Dept Geol, Dalhousie Univ (Ade-Hall et al, 1974). Comment: $\mathrm{NaOH}$ pretreatment.

\section{Spain}

P-2408. Cave of Canet, Majorca

Charcoal layer in Trench 1 at $3.10 \mathrm{~m}$ depth in Cave of Canet, Esporles, Majorca, Spain, $100 \mathrm{~m} \mathrm{~S}$ of Palma-Esporles rd at km $14\left(39^{\circ} 36^{\prime} \mathrm{N}, 6^{\circ} 18^{\prime}\right.$ E). Sample stratigraphically assoc with travertine layer in Test Trench 4, overlying polarity reversal episode in palaeomagnetic log of that trench. Sample coll 1975 and subm by J S Kopper, C W Post College, Long Island Univ, New York. Comment (JSK): date appropriate for Gothenburg polarity reversal episode, 12,000 BP. Comment: date calculated with 5730 half-life, but not corrected $=7500+590,-510 \mathrm{BC}$.

\section{Correction} $\pm 90 \mathrm{BC}$.

$\mathrm{R}, 1975$, v 17, p 205: P-2029, MASCA corrected date should be 4380

\section{REFERENCES}

Ade-Hall, J M, Aumento, F, Muecke, G K, MacDonald, A, Hyndman, R D, Quintino, J, Opdyke, N, and Lowrie, W, 1974, Deep drilling on Sao Miguel, Azores: preliminary results: Am Geophys Union Trans, v 55, p 454.

Agrawal, D P and Kusumgar, Sheela, 1975, Tata Institute radiocarbon date list XI: Radiocarbon, v 17, p 219-225.

Alessio, M, Bella, F, Improta, S, Belluomini, G, Cortesi, C, and Turi, B, 1970, University of Rome carbon-14 dates VIII: Radiocarbon, v 12, p 599-616.

Amiran, R, 1965, A preliminary note on the synchronisms between the early bronze strata of Arad and the first dynasty: Am Schools Oriental Research Bull, no. 179, Oct, p 30-33.

1969, A second note on the synchronisms between early bronze age Arad and the first dynasty: Am Schools Oriental Research Bull, no. 195, Oct, p 50-53. 1970, The beginnings of urbanization in Canaan, in: Sanders, J A (ed), Near eastern archaeology in the twentieth century: New York, Doubleday, p 83-100.

Arnold, J R and Libby, W F, 1951, Radiocarbon dates: Sci, v 113, Feb, p 111-120.

Atzeni, Enrico, 1972, Genna Maria (Villanovaforru): Riv Sci Preistoriche, v 27, p $476-477$.

Barker, Harold, Burleigh, Richard, and Meeks, Nigel, 1969, British Museum natural radiocarbon measurements VI: Radiocarbon, v 11, p 278-294.

1971, British Museum natural radiocarbon measurements VII: Radiocarbon, v 13, p 157-188.

Barker, Harold and Mackey, C J, 1959, British Museum natural radiocarbon measurements I: Radiocarbon, v 1, p 81-86.

Baudez, C F, 1967, Recherches archeologiques au Costa Rica: Paris Travaux et Mém Inst Hautes Etudes Amérique Latine, 18, p 18-25.

Baudez, C F and Coe, M D, 1962, Archaeological sequences in northwestern Costa Rica: Akten des 34 internatl Amerikanisten kong, Wien 1960, v I, p 366-373.

Berger, Rainer, 1970, Ancient Egyptian radiocarbon chronology: Royal Soc [London] Philos Trans, A 269, p 23-26.

Berger, Rainer, Fergusson, G J, Libby, W F, 1965, UCLA radiocarbon dates IV: Radiocarbon, v 7, p 336-371.

Betancourt, P P and Weinstein, G A, 1976, Carbon-14 and the beginning of the late bronze age in the Aegean: Am Jour Archaeol, v 80, no. 4, p 329-348.

Biggs, R D, 1966, The Abu Salabikh tablets: a preliminary survey: Jour Cuneiform Studies, v 20, no. 2, p 73-88.

Bovington, Charles, Mahdavi, Azizeh, and Masoumi, Roghiyeh, 1973, Tehran University Nuclear Centre radiocarbon dates II: Radiocarbon, v 15, p 592-598. 
Bronson, B, Basoeki, Machi Soehadi, and Wisseman, J, 1973, Laporan Penelitan di Sumatra, 1973: Lembaga Purbakala, Jakarta, p 11-12.

Buckley, James, 1976, Isotopes' radiocarbon measurements XI: Radiocarbon, v 18, p $172-189$.

Callaway, J A, 1972, The early bronze age sanctuary at Ai (et-Tell): London, Quaritch,

Callow, W J, Barker, M J, and Hassall, G I, 1965, National Physical Laboratory radiocarbon measurements III: Radiocarbon, $\mathrm{v} 7$, p 156-161.

Callaway, J A and Wagner, N E, 1974, A re-examination of the lower city at Ai (et-Tell) in 1971, 1972: Palestine Exped Quart, July-Dec, p 147-155.

Carnarvon, G E and Carter, H, 1912, Five years' exploration at Thebes: Oxford, Oxford Univ Press, $100 \mathrm{p}$.

Carpenter, R J and Ryan, Kathleen, 1975, TL dating of burnt soil: MASCA Newsletter, v 11 , no. 2 , p 7 .

Chittick, Neville, 1974, Excavations at Aksum 1973-4: a preliminary report: Azania, v 9, p 159-205.

Cockburn, A, Barraca, R, Reyman, T, and Peck, W, 1975, Autopsy of an Egyptian mummy: Sci, v 187 , no. 4182 , p $1555-1560$

Coe, M D, 1962, Preliminary investigations in coastal Guanacaste, Costa Rica: Akten des 34 internatl Amerikanisten kong, Wien 1960, v 1, p 366-373.

Coe, M D and Baudez, C F, 1961, The zoned bichrome period in northwestern Costa Rica: Am Antiquity, v 26, p 505-515.

Daressy, G, 1912, Catalogue of the objects discovered in the tombs of Harmhabi and Touatankamanou, in: Davis, $\mathbf{T}$ M, Excavations: Biban el Moluk, $\mathrm{v}$ 7, London, Constable \& Co, Ltd, p 97-109, 125-135.

Deevey, E S, Flint, R F, and Rouse, Irving, (eds), 1967, Radiocarbon measurements: comprehensive index 1950-1965, New Haven, Yale Univ Press, 221 p.

de Vries, H and Waterbolk, H T, 1958, Groningen radiocarbon dates II: Sci, v 128, Dec, p 1550-1556.

Dupree, Louis, 1958, Shamshir Ghar: historic cave site in Kandar province, Afghanistan: Anthropol Papers Am Mus Nat Hist, v 46, pt 2, p 141-314.

1963, Deh Morasi Ghundai: a Chalcolithic site in south-central Afghanistan: Anthropol Papers Am Mus Nat Hist, v 50, pt 2, p 57-136.

Fairservis, W A Jr, 1959, Archaeological surveys in the Zhob and Loralai districts, West Pakistan: Anthropol Papers, Am Mus Nat Hist, v 47, pt 2, p 277-448.

Fanning, Thomas, 1972, Excavations of a ringfort at Narraghmore, Co Kildare: Jour Co Kildare Archaeol Soc, v 15, p 171-177.

French, D H, 1971, An experiment in water sieving: Anatolian Studies, v 21, p 59-64.

Galanopoulos, A G, 1958, Zur bestimmung des alters der Santorin-kaldera: Annales Géol Pays Helleniques, v 9, p 185-188.

Greiss, E A M, 1957, Anatomical identification of some ancient Egyptian plant materials: Mém Inst Egypte, v 55, Cairo, 165 p.

Habachi, Labib, 1968, The owner of tomb no. 282 in the Theban necropolis: Jour Egyptian Archaeol, v 54, p 107-113.

Hayes, W C, 1935, Royal sarcophagi of the XVIII dynasty: Princeton, Princeton Univ Press, $211 \mathrm{p}$.

1959, The scepter of Egypt, v II: Cambridge, Massachusetts, Harvard Univ Press, 496 p.

1970, Chronology-Egypt to end of the twenticth dynasty: Cambridge ancient history, 3rd ed, v 1, pt 1: Cambridge, Cambridge Univ Press, p 173-193.

Hedrick, J D, 1971, Lapita style pottery from Malo island: Jour Polynesian Soc, v 80, p $5-19$

Helbaek, Hans, 1974, Grain from the Tell Siran bottle: Annals Dept Antiquities, Jordan, v 19 , p $167-168$.

Hölscher, U, 1934-1954, The excavation of Medinet Habu ( 5 v): Chicago, Univ Chicago Oriental Inst Pubs, v 21, 4 p; 41, 123 p; 54, 87 p; 55, 54 p; 66, 81 p.

Jacobsen, T W, 1968, Investigations at Porto Cheli-Halieis, 1967: Archaiol Deltion, v 23, p 144-148.

1969a, Investigations at Porto Cheli, 1968: Archaiol Deltion, v 24, p 135-139.

1969b, The Franchthi cave: Archaeol, v 22, no. 1, p 4-9.

1969 c, Excavations at Porto Cheli and vicinity, preliminary report, II: the Franchthi cave: Hesperia, v 38, no. 3, p 348-381.

1973a, Excavations in the Franchthi cave, 1969-1971, pt I: Hesperia, v 42, no. $1, \mathrm{p}$ 45-88. 
Jacobsen, T W, 1973b, Excavations in the Franchthi cave, 1969-1971, pt II: Hesperia, v 42, no. 3, p 253-283.

1974, New radiocarbon dates from Franchthi cave: a preliminary note regarding collection of samples by means of flotation: Jour Field Archaeol, $v 1$, no. $3 / 4$, p 303-304.

1976, 17,000 years of Greek prehistory: Scientific Am, v 234, no. 6, p 76-87.

Johnson, G A, 1973, Local exchange and early state formation in southwestern Iran: Anthropol Paper no. 51, Mus Anthropol, Univ Michigan, 205 p.

Kees, H, 1953, Das priestertum im ägyptischen staat vom neuen reich bis zur spätzeit: Leiden, E J Brill, 324 p.

Kigoshi, K, Suzuki, N, and Fukatsu, H, 1973, Gakushuin natural radiocarbon measurements VIII: Radiocarbon, v 15, p 42-67.

Kohler, E L and Ralph, E K, 1961, C-14 dates in the Mediterranean area: Am Jour Archaeol, v 65, p 357-367.

Lange, F W, 1971, Culture history of the Sapoa river valley: Occasional Papers in Anthropol, 4, Logan Mus Anthropol, Beloit Coll, p 130, fig 33.

Lawn, Barbara, 1970, University of Pennsylvania radiocarbon dates XIII: Radiocarbon, v 12, no. 2, p 577-589.

v 13, p 363-377.

1974, University of Pennsylvania radiocarbon dates XVII: Radiocarbon, v 16, p 219-237.

v $17, \mathrm{p}$ 196-215.

Le Breton, Louis, 1957, The early periods at Susa, Mesopotamian relations: Iraq, v 19, p 79-124.

Lefebvre, G, 1929a, Inscriptions concernant les grands prêtres d'Amon Romê-Röy et Amenhotep: Paris, P Geuthner, $77 \mathrm{p}$. $1929 \mathrm{~b}$, Histoire des grands prêtres d'Amon de Karnak jusqu'à la XXI dynastie: Paris, $\mathrm{P}$ Geuthner, $303 \mathrm{p}$.

Lucas, A, 1962, Ancient Egyptian materials and industries, 4th ed revised by Harris, J R: London, Edward Arnold, 523 p.

Marinatos, Spyridon, 1968, Excavations at Thera: first preliminary report (1967 season): Athens, Bibliotheke tes en Athenais Archaiol Etaireias, no. 64, p 1-59.

1969, Excavations at Thera I (1968 season): Athens, Bibliotheke tes en Athenais Archaiol Etaireias, no. 64, p 1-54.

1970a, Further news from Marathon: Archaiol Analekta ex Athenon, v 3, p 153-166.

1970b, Excavations at Thera III (1969 season): Athens, Bibliotheke tes en Athenais Archaiol Etaireias, no. 64, p 1-68.

1971, Excavations at Thera IV (1970 season): Ibid, p 1-54.

1972, Excavations at Thera V (1971 season): Ibid, p 1-47.

1973, Excavations at Thera VI (1972 season): Ibid, p 1-60.

1974, Excavations at Thera VII (1973 season): Ibid, p 1-60.

Mellink, M J, 1972, Excavations at Karatas-Semayük and Elmali, Lycia, 1972: Am Jour Archaeol, v 77, p 293-303.

Michael, Henry, 1976, Radiocarbon dates from Akrotiri on Thera: Temple Univ Aegean Symposium, Philadeiphia 1976, p 7-9.

Michael, Henry and Ralph, E K, 1974, University of Pennsylvania radiocarbon dates XVI: Radiocarbon, v 16, p 198-218.

Mughal, M R, 1972, Explorations in northern Baluchistan: Pakistan Archaeol, no. 8, p 137-150.

1974, Explorations in northern Baluchistan, 1972; new evidence and fresh interpretation: in, Bagherzadeh, $F$ (ed), IInd ann symposium archaeol research in Iran Proc, Tehran, p 276-286.

Nakhla, S M and Mohammed, F M, 1974, Cairo natural radiocarbon measurements I: Radiocarbon, v 16, p 1-5.

Navarra, Fernand, 1956, J'ai trouvé l'Arche de Noë: France-Empire, 68, Rue JeanJacques Rousseau, Paris I.

Olsen, E A and Broecker, W S, 1959, Lamont natural radiocarbon measurements V: Radiocarbon, v 1, p 1-28.

Pichler, Hans and Friedrich, Walter, 1976, Radiocarbon dates of Santorini volcanics: Nature, v 262, no. 5567, p 373-374. 
Plantikow-Münster, M, 1969, Die inschrift des B3k-n-hnsw in München: Zeitschr f Ägyptische Sprache u Altertumskunde, v 95, p 117-135.

Ralph, E K, 1959, University of Pennsylvania radiocarbon dates IIr: Radiocarbon, $\mathrm{v} 1, \mathrm{p}$ 45-58.

Ralph, E K and Michael, H N, 1967, Problems of the radiocarbon calendar: Archaeometry, v 10, p 3-11.

1970, Correction factors applied to Egyptian radiocarbon dates from the era before Christ: in, Nobel Symposium 12, Radiocarbon variations and absolute chronology, Olsson, U (ed), Stockholm, Almqvist and Wiksell, $649 \mathrm{p}$.

Ralph, E K, Michael, H N, and Han, M C, 1973, Radiocarbon dates and reality: MASCA Newsletter, v 9, no. 1, August, p 1-20.

Ralph, E K and Stuckenrath, Robert Jr, 1962, University of Pennsylvania radiocarbon dates V: Radiocarbon, v 4, p 144-159.

Schacht, R M, 1975, A preliminary report on the excavations at Tepe Sharafabad, 1971: Jour Field Archaeol, v 2, no. 4, p 307-329.

Sedat, D W and Sharer, R J, in press, The Verapaz archaeological project: the 1972. 1973 seasons: Natl Geog Soc Research Repts, in press.

1973, Preclassic populations and writing systems in the Salama Valley, Guatemala: paper presented at 72 nd ann $m$ tg Am Anthropol Assoc, New Orleans.

Seele, K C, 1959, The tomb of Tjanefer at Thebes: Chicago, Univ Chicago Oriental Inst pubs, $\mathrm{v} 86,10 \mathrm{p}$.

Sharer, R J and Sedat, D W, 1973, Monument 1, El Porton, Guatemala, and the development of Maya calendrical and writing systems: Contr Univ California Research Facility, no. 18, p 177-194.

Shear, T L, 1973, The Athenian Agora: excavations of 1971: Hesperia, v 42, no. 2, p $121-179$.

Stacul, Giorgio, 1969, Excavations near Ghalighai (1968) and chronological sequence of proto-historical cultures in the Swat Valley (W Pakistan): East and West, v 19, p 44-91.

tions (ca 1500-300 BC): East and West, v 20, p 92-102.

Stein, M A, 1929, An archaeological tour in Waziristan and northern Baluchistan: Mem Archaeol Survey India, no. 37, Calcutta, p 1-97.

Stuckenrath, Robert Jr, 1963, University of Pennsylvania radiocarbon dates VI: Radiocarbon, v 5, p 82-103.

Stuckenrath, Robert Jr, Coe, W R, and Ralph, E K, 1966, University of Pennsylvania radiocarbon dates IX: Radiocarbon, v 8, p 348-385.

Stuckenrath, Robert Jr and Mielke, J E, 1973, Smithsonian Institution radiocarbon measurements VIII: Radiocarbon, v 15, p 388-424.

Stuckenrath, Robert Jr and Ralph, E K, 1965: University of Pennsylvania radiocarbon dates VIII: Radiocarbon, v 7, p 187-199.

Stuiver, Minze and Decvey, E S, 1961, Yale natural radiocarbon measurements VI: Radiocarbon, v 3, p 126-140.

Täckholm, Vivi, 1956, Students' flora of Egypt: Cairo, Anglo-Egyptian Bookshop, $649 \mathrm{p}$.

Taylor, R E, 1975, UCR radiocarbon dates I: Radiocarbon, v 17, p 396-406.

Thompson, H O, 1973, The excavation of Tell Siran (1972): Annals Dept Antiquities, Jordan, v 18, p 5-13.

Thorsteinsson, R and Kerr, J W, 1967, Cornwallis Island and adjacent smaller islands: Canadian Arctic Archipelago, Geol Survey Canada Papers, p 64-67.

Valastro, S Jr, Davis, E M, and Varela, A G, 1972, University of Texas at Austin radiocarbon dates IX: Radiocarbon, v 14, p 461-485.

Vogel, J C and Waterbolk, H T, 1967, Groningen radiocarbon dates VII: Radiocarbon, v 9, p $107-155$.

Wailes, Bernard, 1974, Excavations at Dun Ailinne, near Kilcullen, 1973: Jour Co Kildare Archaeol Soc, v 15, no. 4, p 335-345.

Weinberg, Saul, 1956, Exploring the early bronze age in Cyprus: Archaeol, v 9, no. 2, p $112-121$.

Weiss, Harvey, 1972, Qabr Sheykheyn: Iran, v 10, p 172-173.

Wheeler, T S, Maddin, Robert, and Muhly, J D, 1975, Ingots and the bronze age copper trade in the Mediterrancan: a progress report: Exped, v 17, no. 4, p 31-39.

Winlock, H E, 1924, The Egyptian expedition 1923-1924: Metropolitan Mus Art Bull Supp, v 19, Dec, p 3-43. March, pt ii, p 3-32. 